\title{
Aspects of DNA Damage from Internal Radionuclides
}

\author{
Christopher Busby \\ Additional information is available at the end of the chapter \\ http://dx.doi.org/10.5772/53942
}

\section{Introduction}

In this chapter, there is insufficient space to exhaustively review the research which has been carried out on internal radionuclide effects. I hope only to highlight evidence which shows that internal radionuclides cannot be assessed by the current radiation risk model, and to suggest some research directions that may enable a new model to be developed, one which more accurately quantifies the real effects of such exposures. The biological effects of exposure to ionizing radiation have been studied extensively in the last 70 years and yet very little effort has gone into examining the health effects of exposure to internal incorporated radionuclides. This is curious, since the biosphere has been increasingly contaminated with novel man-made radioactive versions of naturally occurring elements which living creatures have adapted to over evolutionary timescales, and intuition might suggest that these substances could represent a significant hazard to health, one not easily or accurately modelled by analogy with external photon radiation (X-rays and gamma rays).

The question of the health effects of internal radionuclide exposures began to be asked in the early 1950s when there was widespread fallout contamination of food and milk from atmospheric nuclear tests. It quickly became the subject of disagreements between two committees of the newly formed International Commission on Radiological Protection (ICRP)[1]. The questions of the equivalence of internal and external radiation exposure, which were the basis of these disagreements, have still not been resolved. In the West, up to very recently, the whole spectrum of health effects from internal incorporated radionuclides has focused on animal studies of Radium, Plutonium and Strontium-90 and human retrospective studies of those individuals exposed to Radium-226 and Thorium-232 in the contrast medium "Thorotrast". These studies suffer from a number of problems which will be discussed. 
Soviet scientists were more interested in internal radiation effects from fission-product radionuclides, but unfortunately their valuable studies have been difficult to access since they are published in Russian. In 1977 Gracheva and Korolev published a book summarising work in this area which was translated in India in 1980 as Genetic Effects of the Decay of Radionuclides in Cells [2]. This presented a wealth of interesting data relating to beta emitter genetic effects in various systems and drew attention to the distinction that must be made between external and internal radiation. This is important since the whole assessment of radiation in terms of health has been through the quantity "absorbed dose" and what can be called the bag-of-water model.

In this bag of water model, illustrated in Fig 1, the total energy transferred by the radiation to living tissue is diluted into a large mass, greater than a kilogram, as if the effects were uniform throughout the tissue being considered. In Fig 1 the tissue mass A represents an external irradiation by $\mathrm{X}$-rays or gamma rays and here the effects are uniform across the tissue. But in the case B, for internal irradiation, it is clear that it is possible, for certain kinds of exposure, for tissue local to the source to receive very large amounts of radiation energy at the same overall energy transfer to the tissue mass.

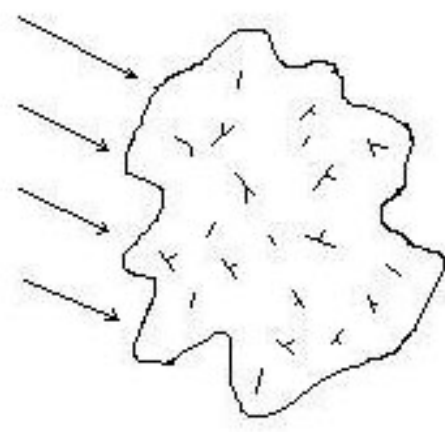

A

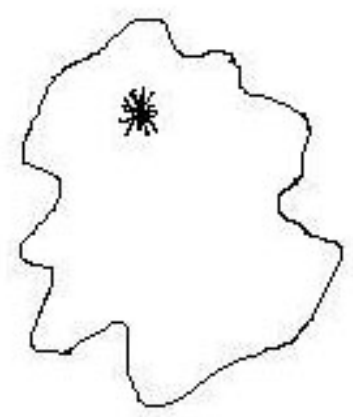

B

Figure 1. Comparing external and internal irradiation: the ICRP/ ICRU bag of water model. In case A, external radiation (X-rays or gamma rays) there are 20 events uniformly spaced throughout the tissue and the "absorbed dose" (see text) at any microscopic point is evenly distributed. In case B, for internal irradiation (here from a radioactive particle) there is a very large transfer of energy to a small tissue volume and the concept of "absorbed dose" does not apply.

Thus, in the historic and also the current system of radiation protection, those experts who assess radiation risk, who are termed Health Physicists, calculate the cumulative absorbed dose in Grays, i.e. in terms of the total energy in Joules imparted by the beta electron or alpha particle decays of the internal radionuclide contamination to one kilogram of tissue. For this calculation, the tissue is modelled as water. For example, those whose body contains $100 \mathrm{~Bq}$ of Strontium-90 are assessed, for the purposes of radiation protection, as having received a cumulative absorbed dose of $100 \mathrm{x} \mathrm{w}$ where $\mathrm{w}$ is the "cumula- 
tive (absorbed) dose coefficient", obtained from measurements of the biological half life of the Strontium in the body and the decay energy of each decay in Joules. This number $\mathbf{w}$ is to be found in a Table published by the ICRP. In the case of the Strontium-90 contaminated individual, if the person weighed $50 \mathrm{~kg}$, then the mean activity concentration would be $2 \mathrm{~Bq} / \mathrm{kg}$. The resulting absorbed dose would then be $2 \times 2.8 \times 10^{-8}$ (this is the ICRP 72 dose coefficient [3]). In other words, the committed dose is $5.6 \times 10^{-8} \mathrm{~Sv}(0.056 \mu \mathrm{Sv})$. But can this be safely compared with a dose from a chest X-ray $(40 \mu \mathrm{Sv})$ or from natural background radiation $(2500 \mu \mathrm{Sv})$ or from a high dose acute exposure to gamma rays from an atomic bomb linearly scaled to zero dose (the current way of modelling radiation effects)? This chapter explores this question. It is one which has become increasingly necessary as serious health effects, including cancer and leukemia, have been reported in those exposed to internal radioactivity in areas contaminated by radionuclides released from nuclear sites, weapons testing fallout and accidents like Chernobyl and Fukushima, at very low conventionally calculated "absorbed doses".

The matter has been discussed in some detail since 1998 by the independent European Committee on Radiation Risk (ECRR) whose reports [4,5] provide a methodology for assessing health effects through a system of weighting factors based on available data. As more and more evidence emerged after 1995 that something was very wrong with the ICRP absorbed dose approach to internal radiation, the UK government set up a Committee Examining Radiation Risk from Internal Emitters (CERRIE). Since there were (and are) political dimensions to the issue, the committee was composed of scientists and experts from the nuclear industry and the official radiation protection organisations in the UK. Unfortunately the 4-years process ended in acrimony, legal threats to member of the committee, and failure to agree a final report. Two reports were issued [6, 7]. However, there was agreement that there were reasonable concerns about the safety of employing "absorbed dose" for certain internal radionuclide situations, and similar concerns about the safety of the ICRP model were made in 2005 by the French IRSN [8]. The error factor that these discussions led to was believed by different ends of the CERRIE process to be between 10-fold and 1000-fold. More recently, the value put on this error factor by the retired Scientific Secretary of the ICRP at a meeting in Stockholm in 2009 was "two orders of magnitude". What this means, in our Strontium-90 case above, is that the dose from $100 \mathrm{~Bq}$ contamination to the whole body is no longer $0.056 \mu \mathrm{Sv}$ but may now be between $0.56 \mu \mathrm{Sv}$ and $56 \mu \mathrm{Sv}$ and the risk of fatal cancer is proportionately increased. To put this in perspective, the mean Sr-90 dose over the period 1959-1963 to individuals in the northern hemisphere was given as about $1 \mathrm{mSv}$ [9]. The ICRP risk model gives a $0.45 \%$ per Sievert excess lifetime cancer risk. Epidemiological studies suggest that the cancer "epidemic" which began in the 1980s in areas of high rainfall and fallout is a consequence of the earlier fallout exposures [10]. The weighting of dose necessary to explain this is greater than 300 if calculated from the ICRP absolute risk factor of $0.05 / \mathrm{Sv}[5,11]$. Many other instances of anomalous health effects from exposure to internal radionuclides require hazard weighting factors of between 100-fold and more than 1000-fold, and these are consequences of mechanisms which will be presented. 


\section{Fundamental principles}

Ionising radiation, however it is delivered, creates harmful effects by causing mutations in genetic material both at the somatic level (cellular DNA) and germ cell level (heritable mutations). The mutations are caused by alterations in the cellular DNA in the nucleus and in mitochondria. These are brought about by three mechanisms:

a. Direct ionisation of the DNA and subsequent chemical alteration of the bases to molecules which are not recognised as a coding signal.

b. Indirect ionisation of the DNA by reactive species produced by ionisation of water (called Reactive Oxygen Species ROS).

c. A mechanism termed "Genomic Instability" which is an inducible cell-cell signal consequence of the production of ROS in the cytoplasm (non-DNA region) of an irradiated cell. This process is communicable between cells in some way and even between individuals and has been termed the "bystander effect".

These mechanisms are well described in the literature and in textbooks, and the processes described here can be found in the reports of radiation protection agencies e.g. [12].

Ionising radiation always transfers its energy to matter in the form of structured tracks of charged particles. Photon radiation (gamma and X-radiation) is absorbed by matter mainly through Compton Effect, Photoelectron, and Pair-production. All these cause the creation of tracks of energetic electrons which carry the energy of the original photon and collide with molecules in the absorbing medium causing ionisation. The ionised fragments (in the case of living tissue mainly of water) then recombine or react with local molecular entities causing chemical changes in the molecular structure. Various chemical reactions take place e.g.

$\mathrm{H}_{2} \mathrm{O}$ (radiation) $\rightarrow \mathrm{H}_{2} \mathrm{O}^{+}+\mathrm{e}^{-}$

$\mathrm{H}_{2} \mathrm{O}^{+}+\mathrm{H}_{2} \mathrm{O} \rightarrow \mathrm{OH}^{*}+\mathrm{H}_{3} \mathrm{O}^{+}$

The free radical $\mathrm{OH}^{*}$ has an unpaired electron and is highly reactive; it will combine with local species including DNA if that is close to the track. If it reacts again with water species the result is a range of highly reactive fragments which are collectively described as Reactive Oxygen Species. The process can be written:

$\mathrm{H}_{2} \mathrm{O}$ (radiation) $\rightarrow \mathrm{e}_{\mathrm{aq}}, \mathrm{H}^{*}, \mathrm{H}_{2} \mathrm{O}_{2}, \mathrm{H}_{2}, \mathrm{OH}^{*}$.

The relative concentrations of the main ROS are [12]:

$\mathrm{e}_{\mathrm{aq}}$ (hydrated electron) $45 \%$

$\mathrm{OH}^{*}$ (hydroxyl radical) $45 \%$

$\mathrm{H}^{*}$ (hydrogen radical) $10 \%$

These reactive species attack molecules in the cell and cause damage; because it is an oxidising agent the $\mathrm{OH}^{*}$ radical is likely to be the most effective DNA damaging agent, abstracting 
a hydrogen atom from the deoxyribose moiety of DNA yielding a highly reactive DNA radical. This will then rearrange or react with local molecules to produce a new molecule in the DNA coding sequence, the gene, a molecule which is unrecognizable to the coding transfer process and alters the message of the gene.

It seems that evolution has recognised the dangers of high levels of cellular ROS and has developed a process to deal with the threat to the species or to the organism. At the organism level the process involves firstly the existence of double strands of DNA which permit repair of ionisation damage to a base located on one strand by copying from the opposite strand. This type of lesion, termed a "point mutation" is a more likely result for chemical mutagenesis or random attack by ROS species present in the cell at some background concentration (as a by product of other chemical processes in the cell). In some cells, the result of DNA damage is programmed cell suicide, termed apoptosis. But at the organism level, one response is the induction of genomic instability, whereby a signal is switched on in the DNA resulting in increased levels of random mutagenesis built into cell replication of the damaged cell and also bystander cells. The exact purpose of this process, which is well documented, is uncertain [13]. If the damage is more extensive, involving locally multiply damaged sites (LMDS) or both strands, it becomes more difficult to accurately repair the material and either a fixed mutation or cell death results.

Internal exposure results from the radioactive decay of radionuclides incorporated into tissue through inhalation or ingestion. There are three principle types of decay which represent the majority of all internal exposures. Gamma decay, which produces fast electron tracks, $\beta$ decay which also produces fast electron tracks, and alpha decay. In addition there are also short range electron tracks from Auger decays. The main internal nuclides of environmental and radiobiological importance are listed in Table 1.

Apart from effects at the nuclide (recoil, transmutation) $\beta$ decay is indistinguishable from the fast (photoelectron) electron tracks produced from gamma and X-ray interactions. With $\beta$-decay, unstable elements change into elements with one greater atomic number $\mathrm{Z}$ and emit an electron in the process; they may also emit a gamma ray. Sometimes the daughter nuclide is also unstable and may further decay. An example is Strontium-90 which emits a $\beta$-particle of endpoint energy $546 \mathrm{keV}$ (kiloelectron volts) and transmutes into Yttrium-90 which further emits a $\beta$-particle of endpoint energy $2280 \mathrm{keV}$ and transmutes into stable Zirconium-90. There are several series decay sequences in which ten or more unstable nuclides are formed, one from another. An example is the natural $\alpha$-emitter Uranium-238 which decays through twelve sequential unstable radionuclides until the sequence stops at stable Lead-206. Transmutation involving $\alpha$-decay involves the change of the chemical element to one with Atomic Number $Z$ four places lower on the Periodic Table. Thus U-238 emits an $\alpha$-particle and decays to Thorium-234.

There is strong evidence that damage to DNA is the cause of the effects of ionising radiation. For example, experiments have been carried out with nuclides which have short range electron emissions (Auger emissions) or Tritium chemically incorporated into DNA precursors so that these elements become covalently bonded to the DNA. The measured harmful effects are up to 100-times greater than would be predicted from the "absorbed dose" showing that 
it is the ionisation in the DNA that is key to the destruction of the cell $[14,15]$. Another argument is based on the effects of the weak $\beta$-emitter Tritium, as tritiated water HTO. The measured effects of Tritium exposure are not too different from that expected on the basis of the absorbed dose (although it may be higher, see below). But clearly the Tritium will be evenly distributed throughout the cell. Since the beta energy of Tritium is only $6 \mathrm{keV}$ the electron track range will be less than $0.5 \mu$ and the ionisations will occur in clusters, uniformly distributed in the cell but with no overlap. It is clear that only those clusters which are close to the DNA will have an effect on the DNA, and the great majority of the energy will be "wasted" in the cytoplasm. Thus for a Tritium dose modelled by ICRP as $1 \mathrm{mSv}$, only a very small fraction of the Tritium decays will contribute to the effect.

The main target DNA, in the cell nucleus, represents a very small fraction of the total material in the cell. In a $10 \mu$ diameter cell (mass $520 \mathrm{pg}$ ) there is $6 \mathrm{pg}$ of DNA made up of $2.4 \mathrm{pg}$ bases, $2.3 \mathrm{pg}$ deoxyribose, $1.2 \mathrm{pg}$ phosphate. In addition, associated with this macromolecule are $3.1 \mathrm{pg}$ of bound water and $4.2 \mathrm{pg}$ of inner hydration water [16]. Since absorbed dose is given as Joules per kilogram, if it were possible to accurately target the DNA complex alone, a dose to the cell (mass $520 \mathrm{pg}$ ) of 1 milliJoule per kilogram (one milliGray, one milliSievert) would, if absorbed only by the DNA complex (6 pg), represent a dose of 520/6 $=87 \mathrm{mSv}$ to the DNA. It is possible to imagine the DNA as an organ of the body, like the thyroid gland or the breast. If this is done, then there should be a weighting factor for its radiobiological sensitivity of 87 which would be based on spatial distribution of dose alone. Of course, for external photon irradiation, to a first approximation, tracks are generated at random in tissue. Therefore only a small proportion of these tracks will intercept the DNA but the interception will be mainly uniform, and the health effects from such external exposure may be assumed to be described by the averaging approach of "absorbed dose". This is not the case for internal exposures from radionuclide decays in a number of quite specific circumstances which will be described below (see [5]).

The calculations of "absorbed dose" also assume that the medium irradiated has uniform isotropic qualities with an absorption coefficient roughly equivalent to that of water. However the absorption of gamma radiation is proportional to the $4^{\text {th }}$ power of the atomic number $\mathrm{Z}$. It follows that the probability of absorption of gamma radiation will be location specific, and this is highly relevant to a number of high $Z$ elements, either biologically necessary (Iodine, $\mathrm{Z}=53$ ) or as contaminants (Uranium $\mathrm{Z}=92$ ) [17].

Radionuclides are primarily chemical elements with the affinities and reactivities of the non-radioactive forms of these elements. They will therefore have quite specific biochemical pathways in the body and may accumulate at positions in cells as a result of their chemical group, valency, ionic volumes, charge etc. This will result in high local doses at sites where they accumulate. In addition, the decay of a nuclide attached to some cell structure or macromolecule will result in the alteration of the radionuclide into a different element with a different charge, with resultant recoil energy. This will always break the chemical bond and result in ionisation. Thus there will be local ionisation and this may be on some critical macromolecule like DNA. These localisation and transmutation effects were studied in the 1960s but no attempt has been made to incorporate them for radiation protection purposes. 
The decay of a radionuclide attached chemically to the DNA is illustrated schematically in Fig 2.
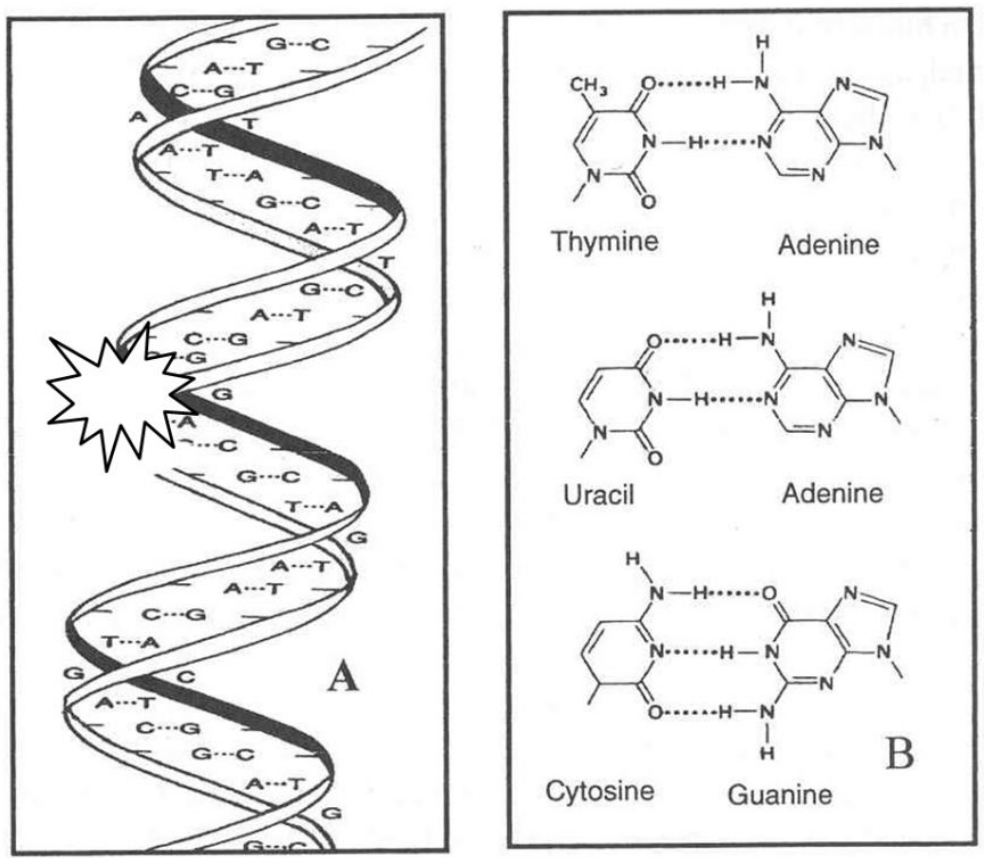

Figure 2. Certain radionuclides (Sr-90, Uranium) bind to DNA and when they decay cause (a) transmutation ionisation and (b) local electron emission ionisation (Auger, $\beta$ particle) on or close to the critical target for radiation effects.

Cells have two phases of activity during their lifespan. They are mostly in a quiescent phase where DNA is not localised spatially. For a short period at the end of their lifespan, when they replicate, they are in a cell cycle phase. In this phase they are much more sensitive to irradiation. Therefore this repair replication phase represents a critical window for mutagenesis if it can be engineered. The radiation sensitivity of the repair replication phase has been studied extensively and it was suggested $[18,19]$ that two irradiation events separated by about 10-12 hours could represent an enhanced hazard since the first pushed quiescent cells into repair replication and the second damaged them during the sensitive 12 hour period. The idea is termed the Second Event theory. There is some evidence for it from work with split doses of X-rays. It will be discussed below.

\section{Concerns about internal radionuclides}

To summarise, the position is that the current assessment of harm from radiation exposure is based on a quantity which does not assume any structure in the tissue being irradiated. It does not 
distinguish between different radionuclides on the basis of their chemical properties except at the organ level (Iodine/ thyroid) and it does not include any weighting for chemical affinities for DNA, nor for transmutation effects. It does not consider the fractionation of doses within cell cycle repair times. Risk factors are based almost entirely on acute external gamma ray exposures. The main concerns are for radionuclides which are significant environmental contaminants and which are listed in Table 3.

\subsection{Proximity effects on local doses}

Since the genotoxic effects of radiation are mediated by ionisation and the local concentration of reactive oxygen species, it is firstly this local ionization density that is the proper measure of the effectiveness of a radiation exposure. The current risk model acknowledges this by weighting the highly ionizing $\alpha$ particle tracks by an arbitrary factor of 20. But of concern is the overlap of such tracks, and of electron tracks from $\beta$-decays or Auger electron showers with active DNA in the nucleus, and especially at the time when this is in some critical state, as in cell repair/division. For externally delivered photon radiation, it can be assumed (in the absence of high- $Z$ photoelectron effects) that ionization is uniform across tissue. Under these circumstances it is only a matter of probability whether a cell is intercepted by a track or not. It has been calculated [20] that, at normal Natural Background levels, each cell in the body will, on the basis of probability, receive one hit per year (a hit being the traversal of the cell by an electron track). Of these hits, some small proportion will involve a track that intercepts the DNA and may cause damage. This damage, if it results in a point mutation, will be repaired before cell division. The ionisation density in a photoelectron track is assumed to be low. Therefore, for external exposure, a dose of $1 \mathrm{mSv}$ to the whole body can be assumed to provide a dose of $1 \mathrm{mSv}$ to the cell on average. At the cell level, this is not the case. A cell can be intercepted by a track or not. If not, then the cell dose is zero and there is no ionisation. If so, then the cell dose can be greater than $1 \mathrm{mSv}$. The dose to the DNA from such processes will again be either zero or some dose greater than $1 \mathrm{mSv}$.

For internal exposures, the probability of interception of the track is clearly a function of the distance of the nuclide from the DNA. In addition, internal exposures may be to $\alpha$ tracks which carry significantly more ionisation density. The range of most $\alpha$ tracks (which carry about of $5 \mathrm{MeV}$ energy) is about 4 cell diameters and so, theoretically, the track dose to the cell from one decay is in the region of $500 \mathrm{mSv}$. The matter becomes serious when the nuclide is an alpha emitter but also has a high chemical affinity for DNA. This is the case for Uranium. Anomalous effects from internal nuclides have been known for a long time. Early studies of cell doses from Tritium were carried out by Apelgot [21] and Robertson and Hughes [22] and reviews of Tritium and of S-35 and P-32 studies are found in ref [2]. In order to emphasise the profound effects which can be identified in internal exposures, the case of Carbon-14 will be examined in greater detail below.

The cell dose from any decay is fairly simple to approximate on the basis of a continuous slowing down approximation and the assumption that the energy delivered along a track is a constant function of the track length. Electron track lengths in tissue for a range of energies 
are given in Table 1. These apply also to photoelectrons which have energies almost equal to the gamma photons that produced them. Assuming a cell diameter of $10 \mu$, the energy deposited in the cell is merely the decay energy divided by the track length in the cell. This is then converted into Joules $\left(1 \mathrm{keV}=1.6 \times 10^{-19} \mathrm{~J}\right)$ and divided by the mass of the cell in $\mathrm{kg}$. For a $10 \mu$ diameter cell this is $5.2 \times 10^{-13} \mathrm{~kg}$. For the Strontium-90 example, a single decay track will deposit approximately $1 \mathrm{mSv}$ in each cell traversed by the track.

\begin{tabular}{llll}
\hline Energy (keV) Range (cms) & $\begin{array}{c}\text { *Linear energy } \\
\text { transfer } \\
\text { keV/ } \boldsymbol{\mu}\end{array}$ & \multicolumn{1}{c}{ Examples (maximum $\boldsymbol{\beta}$-energy, keV) } \\
\hline 5 & $1.2 \mathrm{E}-4$ & 4 & Tritium (5.7) \\
\hline 15 & $5.2 \mathrm{E}-4$ & 2.9 & \\
\hline 20 & $8.6 \mathrm{E}-4$ & 2.3 & Sulfur-35 (167);Carbon-14 (155) \\
\hline 150 & $2.8 \mathrm{E}-2$ & 0.53 & $\begin{array}{l}\text { Strontium-90 (546) Caesium-137 (514) lodine-131 (607) Caesium-134 } \\
\text { (658) Barium-140 (168) }\end{array}$ \\
\hline 1000 & $1.78 \mathrm{E}-1$ & 0.28 & lodine-132 (1610,1210,1040) Barium-140 (1020,1010) \\
\hline 2000 & $9.92 \mathrm{E}-1$ & 0.22 & Yttrium-90 (2280) lodine-132 (2160) \\
\hline
\end{tabular}

* this is simply the loss of energy of the particle over unit distance

Table 1. Continuous slowing down range in muscle tissue for electrons in $\mathrm{g} \mathrm{cm}^{-2}$ (values very similar to range in water) (from ICRU Report 35 Table 2.5 [23])

\subsection{Calculating the spatial effect enhancement}

The spatial effect enhancement is the probability of an ionisation track from an internal nuclide intercepting the DNA at some given level of ionisation density, compared with the probability of this happening from external radiation.

Thus we take the mutagenic event of interest to be associated with absorbed dose (energy per unit mass) in a volume element of a track which is coincident with active DNA in space and time. For nuclides with chemical affinity for DNA this ratio is clearly very large. In the limiting case of covalent binding it can be assumed that approximately half of the decays of the bound nuclide traverse the DNA, and in addition the transmutation of the nuclide causes a point ionisation at its position. In the limit this probability will be 1; for example, C-14 which is incorporated into one of the DNA bases will decay and change into Nitrogen. This will immediately destroy the purine or pyrimidine base which it is part of and will introduce a mutation which may or may not be repaired.

The probability of the interception of a charged particle track intercepting the DNA depends on the distance of the point source and the dimensions of the DNA target employed. The cross sectional diameter of one strand is about $0.3 \mathrm{~nm}$ but, in mitosis, various much larger 
condensed targets exist. The principle is the same, however: the probability of intercepting the target falls off rapidly with distance. The result for a condensed DNA target of cross section $0.1 \times 1 \mu$ is given in Fig 3. The calculation is given in Appendix A. The result confirms what is intuitively obvious: the effect of radionuclide decay in the cytoplasm is much less harmful than for nuclides bound to DNA. This is particularly significant for the $\alpha$-emitters which have chemical affinity for DNA, Uranium $\left(\right.$ as $\left.\mathrm{UO}_{2}{ }^{++}\right)$and, possibly, Plutonium.

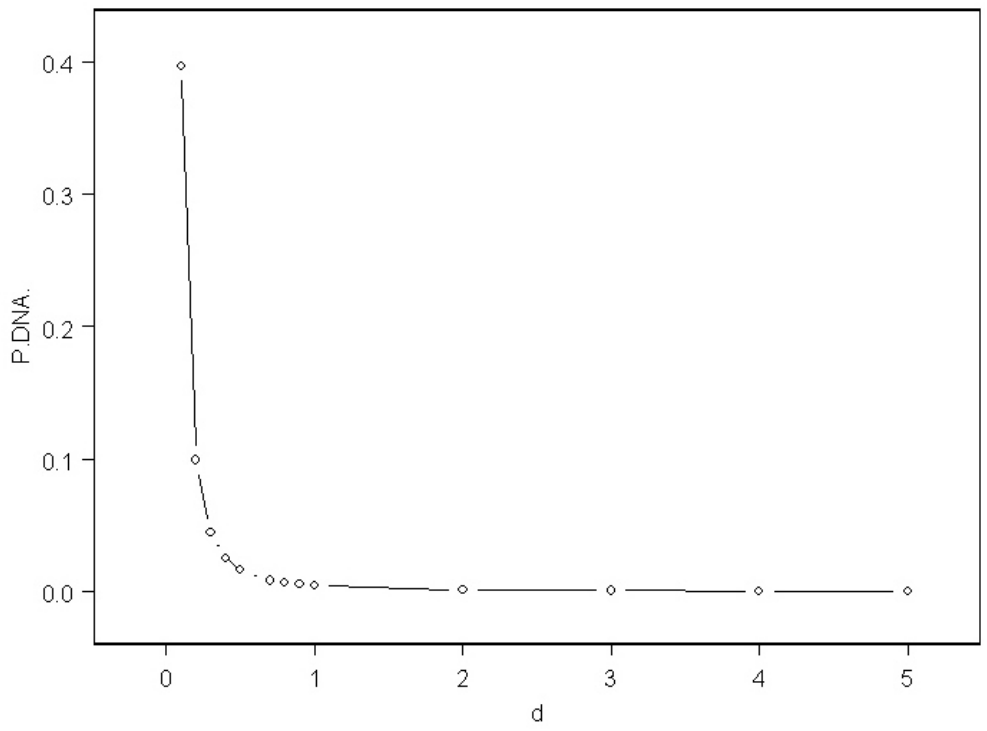

Figure 3. Approximate probability of a track interception of a DNA target modelled as a strip of $0.1 \times 1 \mu$ by distance in $\mu$ from target. In this model, the maximum probability is 0.5 for a nuclide located on the surface of a flat strip.

One other simple way to illustrate this spatial effect is merely to consider the tissue as two compartments, an organ A which may be called "DNA" and one B which may be called "everything else". The current ICRP risk model calculates the absorbed dose of any internal exposure by dividing the total decay energy by the mass. This would not distinguish between compartments A and B; both would receive the same dose. But as far as cancer is concerned (or other consequences of genetic damage) all the ionisation in compartment B is wasted. It has no effect. Therefore it is the dose to compartment $\mathrm{A}$ that is the cause of the effect. This would suggest that the spatial enhancement is at minimum the ratio MassB/MassA or about 90-fold. This assumes that all the DNA in the cell is a critical target which is unlikely to be the case. If the critical DNA represented even $1 / 10^{\text {th }}$ of the total cellular DNA, the spatial enhancement from track interception alone would be 900 -fold. 


\subsection{Double strand breaks}

At natural background radiation levels, where there is one "hit" per cell per year, the Poisson probability of multiple tracks across the DNA strand is low. Most of the "hits" are repairable and the biological response is proportional to the dose. But it is believed on the basis of good evidence that genetic mutations result from multiply damaged sites [12]. If two adjacent DNA strands are broken, then repair is not possible since there is no template from which to copy the correct sequence. Ward et al. (1988) [16] compare DNA damage necessary to inactivate exposed cells between radiation and chemical mutagens. Table 2 lists some of the results:

\begin{tabular}{lll}
\hline \multicolumn{1}{c}{ Agent } & \multicolumn{1}{c}{ DNA lesion } & No of lesions per cell \\
\hline lonizing radiation & SSB & 1000 \\
\hline & DSB & 40 \\
\hline Benzo[a]pyrene 4,5 oxide & Total LMDS & 440 \\
\hline methylnitrosourea & Carcinogenic adduct & 100,000 \\
\hline Aflatoxin & 7-methylguanine & 800,000 \\
\hline
\end{tabular}

Table 2. Yields of DNA damage necessary to kill $63 \%$ of exposed cells [16]

From Table 2 it is clear that ionizing radiation is more effective than the most powerful chemical carcinogens in causing genetic lesions to the DNA, but it is the double strand breaks (DSBs) and LMDS which are the most efficient processes. From simple kinetic theory it is clear that the probability of inducing double strand breaks or LMDS will increase as the number of tracks per unit time increases. At low background external doses this is very unlikely. But as the dose rate increases, so the likelihood of multiple tracks increases (for a discussion see [18]). This is not true for a number of internal exposure situations where multiple tracks can occur at very low doses, conventionally assessed. The first is exposure to particulates.

Radioactivity from releases from nuclear explosions, e.g. accidents like Chernobyl, or from weapons tests or Uranium weapons is partly in the form of sub-micron particulates which are respirable and can be translocated from the lung. Tissue near such particles will receive multiple tracks even though the dose, as assessed as energy per unit mass may be very low. Similar multiple track effects can occur close to high $\mathrm{Z}$ element particles whether they are intrinsically radioactive or not, e.g. platinum (catalysers), bismuth, gold (prostheses), due to secondary photoelectron conversion from natural background gamma radiation $[7,17]$. The second is where a relatively immobilised nuclide has a sequential decay pathway and so there is more than one decay from approximately the same position. This situation is more genotoxic when the decays occur within the repair replication cycle; the Second Event [7] and this situation will be discussed separately. 


\begin{tabular}{|c|c|c|c|c|}
\hline Radionuclide & $\begin{array}{l}\text { Half life } \\
\text { (Decay } \\
\text { product) }\end{array}$ & Decay & Reasons for concern & Other remarks \\
\hline Tritium H3 & $\begin{array}{l}12.32 \text { y } \\
\text { Helium-3 }\end{array}$ & $\begin{array}{l}\text { Low energy } \\
\beta\end{array}$ & $\begin{array}{l}\text { Ubiquitous; Discharged in large } \\
\text { amounts by all nuclear sites and } \\
\text { weapons tests; present as tritiated } \\
\text { water and easily incorporated into } \\
\text { body. Can be present as organically } \\
\text { bound tritium which may accumulate } \\
\text { in the body. }\end{array}$ & $\begin{array}{l}\text { Evidence of serious genetic } \\
\text { effects in invertebrate } \\
\text { development at very low doses; } \\
\text { short range of } \beta \text { decay causes } \\
\text { high ionisation density. }\end{array}$ \\
\hline Carbon-14 & $\begin{array}{l}5730 y \\
\text { Nitrogen }\end{array}$ & $\beta$ emitter & $\begin{array}{l}\text { Discharged by nuclear sites, } \\
\text { particularly reprocessing sites } \\
\text { (Sellafield) and weapons tests. } \\
\text { Incorporated into the carbon of the } \\
\text { body }\end{array}$ & $\begin{array}{l}\text { Doses by ingestion mainly of } \\
\text { vegetables, milk, fish. Both } \\
\text { Carbon and hydrogen (Tritium) } \\
\text { make up the structure of living } \\
\text { systems. Transmutes to a gas, } \\
\text { nitrogen. }\end{array}$ \\
\hline Sulphur-35 & $\begin{array}{l}87 \text { days } \\
\text { Chlorine }\end{array}$ & $\beta$ emitter & $\begin{array}{l}\text { Discharged from nuclear sites. } \\
\text { Concentrates in foods. }\end{array}$ & $\begin{array}{l}\text { Sulphur also a part of internal } \\
\text { macromolecules in living } \\
\text { systems. Transmutes to a } \\
\text { reactive gas, Chlorine }\end{array}$ \\
\hline Strontium-90 & $\begin{array}{l}28.9 \text { y } \\
\text { Yttrium-90 }\end{array}$ & $\beta$ emitter & $\begin{array}{l}\text { Globally Widespread. Atmospheric } \\
\text { test fallout, nuclear sites, accidents } \\
\text { (Chernobyl, Fukushima); Group } 2 \\
\text { affinity for DNA }\end{array}$ & $\begin{array}{l}\text { Second event nuclide with } \\
\text { daughter Y-90 of concern since } \\
\text { it binds to DNA }\end{array}$ \\
\hline Krypton-85 & $\begin{array}{l}10.7 \text { y } \\
\text { Rubidium-8 } \\
5\end{array}$ & $\beta$ emitter & $\begin{array}{l}\text { Very large amount routinely released } \\
\text { from nuclear sites is building up in } \\
\text { atmosphere. }\end{array}$ & $\begin{array}{l}\text { Very soluble in fats and } \\
\text { therefore can build up in body } \\
\text { fat (beast tissue, lymphatic } \\
\text { tissue) following inhalation }\end{array}$ \\
\hline Barium-140 & $\begin{array}{l}12 \mathrm{~d} \\
\text { Lanthanum } \\
-140\end{array}$ & $\beta$ emitter & $\begin{array}{l}\text { Large quantities from nuclear } \\
\text { weapons tests; Group } 2 \text { affinity for } \\
\text { DNA }\end{array}$ & $\begin{array}{l}\text { Second event emitter binds to } \\
\text { DNA. Of concern in assessing } \\
\text { effects of nuclear atmospheric } \\
\text { tests and accidents }\end{array}$ \\
\hline lodine-131 & $\begin{array}{l}8 \text { days } \\
\text { Xenon-131 } \\
\mathrm{m}\end{array}$ & $\beta \gamma$ emitter & $\begin{array}{l}\text { Large amounts from accidents, } \\
\text { licensed releases. Affinity for Thyroid } \\
\text { and Thyroxine in circulating blood }\end{array}$ & $\begin{array}{l}\text { Second event emitter with } \\
\text { daughter Xe-131m short half } \\
\text { life. Transmutes to a gas. }\end{array}$ \\
\hline Tellurium-132 & $\begin{array}{l}3.25 d \\
\text { lodine-132 }\end{array}$ & $\beta \gamma$ emitter & $\begin{array}{l}\text { Released in large amounts from } \\
\text { accidents; daughter is lodine } 132\end{array}$ & Second event series \\
\hline Caesium-134 & $\begin{array}{l}2 \text { y } \\
\text { Barium-134 }\end{array}$ & $\beta \gamma$ emitter & $\begin{array}{l}\text { Released from nuclear explosions, } \\
\text { accidents }\end{array}$ & Binds to muscle \\
\hline Caesium-137 & $\begin{array}{l}30 \text { y } \\
\text { Barium-137 } \\
\text { m }\end{array}$ & $\beta y$ emitter & $\begin{array}{l}\text { Released from nuclear explosions, } \\
\text { accidents, nuclear sites under licence }\end{array}$ & $\begin{array}{l}\text { Binds to muscle; concerns over } \\
\text { effects on heart in Chernobyl } \\
\text { contaminated areas. }\end{array}$ \\
\hline
\end{tabular}




\begin{tabular}{|c|c|c|c|c|}
\hline Radionuclide & $\begin{array}{l}\text { Half life } \\
\text { (Decay } \\
\text { product) }\end{array}$ & Decay & Reasons for concern & Other remarks \\
\hline Radium-226 & $\begin{array}{l}1599 y \\
\text { Radon-222 }\end{array}$ & a emitter & $\begin{array}{l}\text { NORM Contamination near oil and } \\
\text { gas processing sites; widely studied } \\
\text { but problems with the studies (see } \\
\text { text). Decays to Radon gas. }\end{array}$ & $\begin{array}{l}\text { Group } 2 \text { Calcium seeker. Binds } \\
\text { to DNA. Evidence of non-cancer } \\
\text { reduction in lifespan in human } \\
\text { studies. }\end{array}$ \\
\hline Polonium-210 & $\begin{array}{l}\text { 139d } \\
\text { Lead-204 }\end{array}$ & a emitter & $\begin{array}{l}\text { Releases from nuclear sites; daughter } \\
\text { of Lead } 201 \text { which can build up in } \\
\text { environment as a result of } \\
\text { contamination from NORM }\end{array}$ & \\
\hline Uranium-238 & $\begin{array}{l}4.5 \times 10^{9} \mathrm{y} \\
\text { Series }\end{array}$ & a emitter & $\begin{array}{l}\text { Releases from nuclear sites; } \\
\text { contamination from mining and } \\
\text { processing; from weapons fallout } \\
\text { and accidents; from battlefield } \\
\text { weapons usage and testing. } \\
\text { Widespread in the environment but } \\
\text { generally not measured near nuclear } \\
\text { sites }\end{array}$ & $\begin{array}{l}\text { High Z photoelectron effects; } \\
\text { binds to DNA; considerable } \\
\text { evidence for its anomalous } \\
\text { genotoxicity }\end{array}$ \\
\hline Plutonium-239 & $\begin{array}{l}2.4 \times 10^{4} \mathrm{y} \\
\text { Uranium-23 } \\
5\end{array}$ & a emitter & $\begin{array}{l}\text { Releases from nuclear sites, weapons } \\
\text { test fallout, widespread } \\
\text { environmental contaminant }\end{array}$ & $\begin{array}{l}\text { Binds to DNA (?) evidence for } \\
\text { anomalous genotoxicity }\end{array}$ \\
\hline
\end{tabular}

Table 3. Internal radionuclides of concern

Third, if an alpha emitting nuclide is either randomly positioned near or chemically attracted to the DNA, there is a significant probability that the highly ionising track will traverse the two strands of the DNA and damage multiple sites. This is the origin of the high efficiency of alpha emitters which resulted in their being weighted by ICRP. Fourth, there are situations where dose is delivered by very low energy beta emitters; the best example is Tritium. Because dose is assessed as energy per unit mass, the very low decay energy of Tritium means that there is a large number of decays from different atoms of Tritium (90 tracks) to deliver the same dose as one $500 \mathrm{keV} \beta$ decay from Caesium-137 or from the traversal of a cell by a $500 \mathrm{keV}$ photoelectron track. This would suggest a mechanism backing the evidence (see below) that Tritium represents a greater mutagenic hazard than is calculated on the basis of its absorbed dose.

\subsection{Summary of enhancement mechanisms; caveats over high dose studies}

The target for radiation effects is the DNA, the nuclear DNA and the sensitivity to radiation varies depending on whether the cell is in quiescent phase or in repair replication. Within the 12 hour repair replication period there are other sensitive windows. The end point for radiation damage to the DNA can be genetic mutation leading to heritable damage (in germ cells) or cancer, but if the ionisation density is too great, or the sequential hits to close to- 
gether then the cell will die. The interesting thing then is that this will decrease the fixed mutation rate and therefore will decrease the cancer rate. Thus we would not expect studies of high dose and high dose rate to elicit information which informs on low dose and low dose rate.

The dose/ dose rate response in cancer studies will inevitably have a complex character for this reason. This is clear from the results of retrospective studies of Radium and Thorotrast contamination, studies which have been influential in supporting the current radiation risk model, an issue with will be discussed further below. The key point is that, for certain internal exposure regimes, the ionisation density at the DNA and the damage to the DNA can be extremely high even though the absorbed dose, as calculated by the current methodology, may be extremely low.

The regions of internal and external dose, are illustrated in Fig 4.

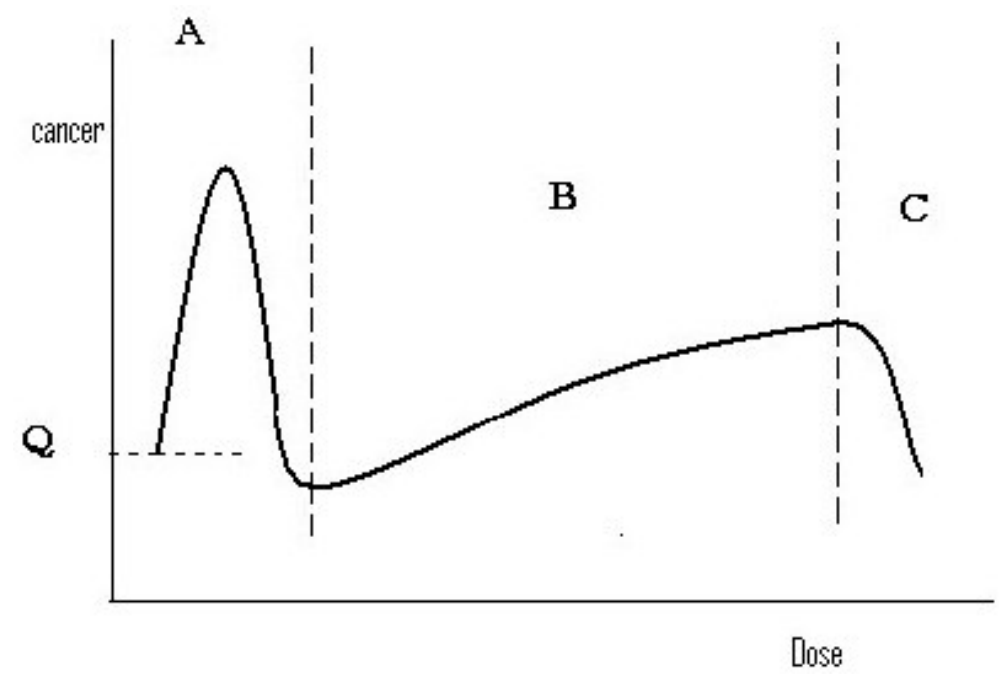

Figure 4. Regions of interest in a theoretically predicted dose response relation (see text and ECRR2010). Exactly this dose response is seen in infant leukemia rates after Chernobyl in Greece, Germany (3 dose regions) Wales, Scotland and Belarus (see [25]).

The analysis from ECRR 2010 [5] is described in Fig 4, the end point is assumed to be cancer rate. $\mathrm{Q}$ is the background rate. There are three regions. In the first region $\mathrm{A}$, sensitive cells in repair replication are first mutated (positive slope) and then overwhelmed (negative slope). Next, in region B the cells in quiescent phase are mutated and eventually overwhelmed in C. This is also the organism response since at high doses $C$ the organism suffers from non cancer causes of death which affect the cancer rates, reducing them as the dose increases. These responses are seen in many epidemiological and animal studies but are generally misinterpreted. Burlakova has made a special study of dose response relationships and has shown the type $\mathrm{AB}$ response for a wide range of objective markers of DNA damage and also whole organism end-points [24].The dose response is seen in, and most easily explained in, infant 
leukemia after internal radiation exposures. As the exposure increases, foetal death ensues at some point, and the leukemia rate in the infant falls [25]. If the dose response is assumed to be linear, and the low dose data points assumed to be data scatter, a line drawn between the background cancer rate $Q$ and the peak in region $B$ cuts the response line in such a way as to suggest that radiation is actually reducing cancer rate, the so-called hormesis theory. The analysis in ECRR2010 points out that this is a misinterpretation of the data.

From what has been discussed, it is possible to summarise the mechanisms that may lead to increased risk of damage to DNA, and indeed to decreased risk in the case of high local doses which will kill rather than fix mutations. The mechanisms are listed in Table 4 where enhancements from alpha emitters with affinity for DNA may deliver such high local doses as to inactivate the cell.

\begin{tabular}{|c|c|c|}
\hline Mechanism & Range & Examples \\
\hline \multicolumn{3}{|l|}{ Spatial location } \\
\hline DNA affinity & $0.1-100$ & Uranium, Strontium, Barium, Radium Plutonium? \\
\hline Membrane affinity & $?$ & Caesium, Potassium, Rubidium, Chlorine, Sodium \\
\hline DNA incorporation & Very high & Tritium, Carbon-14 \\
\hline Particulates & $10-1000$ & Uranium. Plutonium \\
\hline Protein incorporation & $?$ & Sulphur-35, Tritium, Carbon-14 \\
\hline Transmutation & $5-100$ & $\begin{array}{l}\text { All covalently bound internal nuclides e.g. Sulphur-35, } \\
\text { Tritium, Carbon-14 }\end{array}$ \\
\hline \multicolumn{3}{|l|}{ Temporal location } \\
\hline $\begin{array}{l}\text { Critical cell lifespan phase interception } \\
\text { by immobilised source }\end{array}$ & $0.01-100$ & $\begin{array}{l}\text { Strontium-90, Tellurium-132, Tritium, Radium-226, } \\
\text { particulates }\end{array}$ \\
\hline $\begin{array}{l}\text { Critical repair replication window } \\
\text { interception }\end{array}$ & $0.01-1000$ & $\begin{array}{l}\text { Strontium-90, Tellurium-132, Tritium, Radium-226, } \\
\text { particulates }\end{array}$ \\
\hline Fat soluble noble gases & $?$ & e.g. $\mathrm{Kr}-85$ \\
\hline $\begin{array}{l}\text { High Atomic Number photoelectron } \\
\text { amplification }\end{array}$ & $\begin{array}{l}U-238 \\
100-1000\end{array}$ & $\begin{array}{l}\text { Uranium, Platinum, Gold, Bismuth, potentially all } \\
\text { elements with Z" />53 }\end{array}$ \\
\hline
\end{tabular}

Table 4. Main mechanisms of enhancement of genetic hazard from internal irradiation (see ECRR2010).

\section{Specific concerns and new research directions}

\subsection{Location enhancement and chemical affinity}

Concern has been shown since the 1950s that radionuclides of Group 2 in the Periodic Table, notably Strontium-90 and Barium-140, may have high affinity for DNA. These ele- 
ments exist in solution as dipositive ions which are known to concentrate in organs (bones, teeth) which have high phosphate concentrations. Calcium and Magnesium are also known to bind electrostatically to the DNA Phosphate backbone and to stabilise its conformation. It is therefore likely that Strontium, Barium and Radium also have such affinity. The concentration of the radiation risk establishment on Radium epidemiology has been based on an end-point of bone cancer because the nuclide concentrates in bone. The affinity for DNA has been overlooked.

In the 1960s, for the reason that it was believed that Strontium would bind to DNA, and because some experiments showed that this was the case, there was significant concern about Strontium-90 contamination of milk. Mouse experiments demonstrated effects on intrauterine foetal death [26], and studies on rats showed development effects from Sr-90 [27]. There were effects at very low doses from Sr-90 [28], and by 1970 the director of the UK Medical Research Council suggested that further interest be taken in research on Sr-90 [29]. However nothing was done. In 2004, the CERRIE committee unanimously called for there to be further research into the effects of exposure to Sr-90 [6]. Also classified with these Group 2 is Uranium which exists in solution as the dipositive ion $\mathrm{UO}_{2}^{++}$the Uranyl ion. This has very high affinity for DNAP [30] which led to its introduction as a chromosome stain for electron microscopy as early as 1960 [31].

The most necessary research is to measure the affinity of Strontium, Radium and Uranyl ion for chromosomes in vivo. Owing to the high opacity of Uranium there are certainly potential electron microscope methods for examining its location in cells in vivo. It might be possible to employ autoradiography to measure the affinity constants in vivo for Ra-226, Sr-90 and Ba-140. Affinity constants for DNAP can be easily measured in vitro for Strontium, Barium and Radium but this does not appear to have been done.

Animal studies of Radium and Uranium have assumed that the end point must be bone cancer or leukemia, and that only high doses will cause cancer. Effects at low doses have been assumed to be random scatter. It is suggested that low dose animal studies be undertaken with lifespan observation of all possible conditions to resolve this issue.

1. There is the question of membrane affinity. If certain ions congregate at certain membranes, the local ionisation density from radioactive decay will be higher than if these were uniformly distributed in cytoplasm. Experiments with the nuclide Sodium-22 by Petkau showed a supralinear dose response and effects at very low doses as calculated by using the total solution volume as a denominator [32]. If such effects occur in vivo there are a number of critical membranes which might be destroyed from internal radionuclide ions. Experiments in vitro might involve K-40, and Cs-137.

2. DNA is made from Carbon, Oxygen, Hydrogen and Nitrogen. Carbon-14 and Tritium can both therefore become covalently bonded into the molecule, and Tritium can easily exchange with labile hydrogen atoms on $-\mathrm{SH},-\mathrm{OH}$ and $-\mathrm{NH}$ moieties. The resultant decay will result in the total internal rearrangement or local reaction resulting in permanent alteration of the molecule. This will produce a point mutation with $100 \%$ efficiency. The electrons from the decay or reactive species created during the trans- 
mutations through abstraction of protons from water may damage other local DNA leading to LMDS or DSBs. In the case of C-14, the transmutation to N-14 will totally destroy the molecule since the two elements have different valency, outer electron structure, and reactivity. Owing to the long half-life of C-14, experiments on its genetic effects have been difficult to carry out. Nevertheless, some studies have been published which show that these transmutation effects dominate the hazards of C-14 and Tritium incorporation (see below).

\subsection{Particulates}

The problem of the anisotropy of dose from internal "hot particles" was raised by Tamplin in the 1980s [33]. It was discussed by CERRIE and was the subject of a review by Charles et al in 2003 [34]. Since the 1950s, there has been a new class of internal radionuclide exposure which has not existed throughout evolution. This is the sub-micron or nanometre diameter radioactive particle. Particles below $1 \mu$ diameter can be inhaled and translocated from the lung to the lymphatic system. They are created in nuclear explosions, from power station accidents, from nuclear site releases and from Uranium weapons on battlefields. Depending on their nuclide composition they can produce very high local doses to tissue in which they become immobilised, but may also, depending on their diameter and composition, produce lower doses. Two concerns are Uranium and Plutonium oxide particles. Both contaminated large areas of land in Europe after Chernobyl. Both are resuspended from coastal sediments where contamination exists e.g. the Baltic Sea and the Irish Sea and plutonium from this latter source has been measured in coastal autopsy specimens [35], sheep faeces, and childrens teeth [36]. The well known Seascale child leukemia cluster [37] was discussed by the authorities [40] who dismissed the idea that the leukemia was caused by inhalation of plutonium and uranium on the basis that the doses to the lymphatic system were below natural background $[38,39]$. However, the methodology employed diluted the particulate energy into a lymphatic system modelled as several kilograms of tissue [38] rather than the tracheobronchial lymph nodes which weigh about then grams and which are known to be the origin of leukemia in some animals.

The problem with the hot particle issue is that there will be a range of local energies (local dose) which will have either little effect (A), a genetic effect (B) or a killing effect (C). This was pointed out in 1986 following Chernobyl [41] and the idea is illustrated in Fig 5. Regions A to $C$ will have dimensions resulting (a) from the activity and composition of the particle and (b) from its diameter. A particularly interesting case is that of a weakly radioactive particle like U-238 produced from battlefield use of Uranium weapons, so called depleted Uranium. Such a particle may be more carcinogenic than the much more radioactive plutonium particles found in the Irish Sea and epidemiology seems to bear this out. Of interest also is the photoelectron amplification of natural background radiation by internal high atomic number particles like Uranium-238, but also other elements (see below). It is not sufficient to dispute the hazards from particulates by pointing out that they will have such high activities that cells will be killed rather than mutated e.g. [34, 6]. 


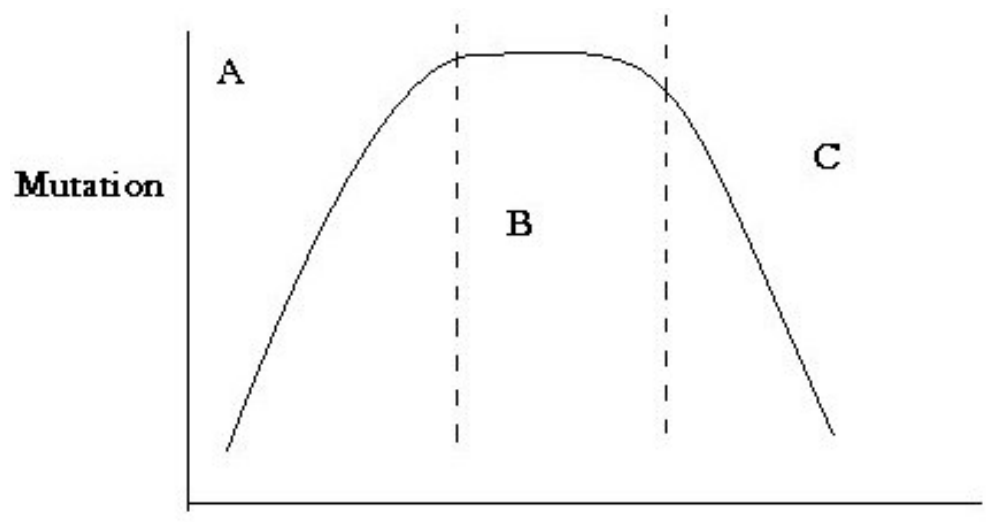

Local Dose

Figure 5. Effects in cells local to "hot particles" (see text).

\subsection{Protein and DNA incorporation and transmutation}

The inactivation of key enzymes or DNA by incorporation through biosynthesis of radionuclide substituted precursors is a matter that seems to have been entirely overlooked in radioprotection. The environmental contamination nuclides which will inactivate biological molecules are those from which they are constituted, namely Carbon (C-14), Hydrogen (Tritium), and Sulfur (S-35). Some results for C-14 and Tritium will be briefly presented. There is an important experiment which shows the contribution of transmutation to the lethal effects of C-14. Apelgot and Latarjet [42, 43] incorporated C-14 into the cells of the bacteria e.coli by culturing in a medium containing 2-14C-thymidine. The samples were stored at $-196 \mathrm{C}$, The specific activity of the $2-{ }^{14} \mathrm{C}$ thymidine was $166 \mathrm{MBq} / \mathrm{milliMol}$. The experiments continued for a year. To evaluate the role of the $\beta$-radiation, a control non-radioactive bacteria sample was stored in the presence of $2{ }^{14} \mathrm{C}$ thymidine in such a way that the radioactivity per $\mathrm{cm}^{3}$ of this suspension was the same as the study sample. From a comparison of the results, the authors concluded that the predominant lethal effect was from transmutation with an efficiency of 160 -times that which would be obtained from the $\beta$-radiation. Similar results have been obtained from studies of C-14 by Anderson and Person [44, 45] who put the hazard coefficient relative to $\beta$-radiation at 10 -fold. These authors studied the mutagenic effect of C-14 and compared transmutation with external X-ray doses. Pluchennik [46, 47] studied the mutagenic effect of $\mathrm{C}-14$ decay in Chlorella grown in a medium containing a single carbon source with different fractions of C-14. The number of mutants from the C-14 rose rapidly at low fractions and quickly saturated due to killing effects; the data showed that the mutagenic effect considerably exceeded that due to external radiation. Other research carried out in the 1960s has largely confirmed this generalisation [2].

The genetic effects of incorporation of C-14 are of concern since the atmospheric nuclear tests in the 1950s and 1960s greatly increased the C-14 in the atmosphere. The genetic hazard 
to man was first pointed out by Totter et al [48] in 1958 and also by Pauling [49]. A number of studies were carried out on different systems. These include onion bulbs [50,51] grown in an atmosphere of ${ }^{14} \mathrm{CO}_{2}$ resulting in chromosome aberrations, micronuclei and elongated cells. Onion bulbs were also studied by Friedkin and Atchison [52] who compared chromosome aberration in the roots between labelled thymidine (incorporated in DNA) and thymine (not incorporated). The frequency of aberrations was 3.95\% for the thymidine but only $0.43 \%$ for the thymine, showing that the effect of transmutation was 9-times that of the $\beta$ -radiation. A study of the effect of the C-14 position in the thymidine [53] showed quite clearly that it was transmutation that was the cause of the effects.

Kuzin et al [54,55] compared the transmutational component of C-14 incorporation with external $\gamma$ radiation in the broad bean. The amount of chromosomal aberration in 2 days was found to be 25-times per rad for the transmutational component. Other studies on drosophila $[56,57]$ give results which suggest that the mutagenic efficiency of C-14 is about three times that of chronic external $\gamma$ radiation. Valuable reviews of effects from Tritium and Sulphur-35 are presented in [2].

Tritium has been increasing in the biosphere since the nuclear atmospheric testing. The main form in which it exists is tritiated water (HTO) but the nuclide also is incorporated into carbon compounds e.g. $\mathrm{CH}_{3} \mathrm{~T}$ and this is termed organically bound Tritium. Tritium is also employed for radioactively labelling compounds in chemical, medical and biochemical research. Tritium has a half-life of 12.6 years and radiates low energy $\beta$-particles $(0-18 \mathrm{keV})$ and when incorporated in a molecule it transmutes to Helium with molecular restructuring and ionisation and realises a recoil energy of $0-3 \mathrm{keV}$. These events convey a high probability of destruction or inactivation of the parent molecule. If this is a macromolecule, local restructuring may alter the tertiary folding structure and inactivate the entire molecule. Thus the effects of Tritium are amplified in the ratio of the molecular mass to the Tritium mass, which may be by orders of magnitude. The question of whether these results show enhancement of effect relative to externally calculated absorbed dose does not seem to have been addressed either for lethality or mutation. Experiments with very low dose exposures of Tritium to invertebrates have identified significant developmental effects [58]. Tritium is also of interest as a pseudo-second event nuclide (see below) owing to the fact that the number of events associated with unit dose is far greater than the mean event number associated with background gamma radiation.

\subsection{Temporal location: The second event theory}

It is well known that dividing cells are more sensitive to radiation than quiescent cells. Once cells are committed to division, they enter the active part of the cell cycle, during which DNA repair takes place followed by cell division. It is therefore clear that any damage or signal which moves cells from quiescence into the repair replication sequence puts the cells into a condition where a second damaging event will carry an enhanced risk of mutation or lethality. This is the basis of the Second Event Theory [18, 19]. This postulates that split doses to the cell DNA, separated by 10-12 hours, will represent an enhancement of hazard. The sequence is vanishingly unlikely for external natural back- 
ground irradiation but exceedingly likely for a number of specific internal sequential emitters. These include exposure regimes involving Sr-90/Y-90, Te-132/I-132 and various others. They include hot particles (since there are continuous releases of tracks from these) and also Tritium which, due to its very low decay energy, produces many more tracks per unit dose than natural background radiation.

The probabilities of second event processes occurring can be calculated but depend on basic assumptions. A paper by Cox and Edwards of the UK National Radiological Protection Board [59] concluded that the cell dose enhancements were finite but low. However it was pointed out that there were major faults in the cell dimensions employed in this study [60]. Clearly, the enhancement is a function of the location of the Second Event nuclide, the factor increasing sharply as the critical volume is reduced. For location on the DNA the potential enhancement becomes enormous. Table 5 shows results for Sr90/Y90. A number of studies have indeed shown anomalous genetic hazard from Sr-90/Y-90 [7, 18]. However, since Strontium also binds to DNA it carries enhancement from other mechanisms. An interesting experiment which suggests that there are $2^{\text {nd }}$ event effects from $\mathrm{Sr}-90 / \mathrm{Y} 90$ was a comparison of the genetic damage effectiveness of Sr-90 and the singly decaying Sr-89 on yeast suspensions at the same doses. The results showed that the Sr90 was four-times as genetically damaging as the Sr89 for the same dose [61]. Further support comes from cell culture experiments with split doses of X-rays which show an enhancement of effect for split dose regimes during the repair replication period $[18,62,63]$. In view of the important implications this has for medical X-ray and radiology the question should be examined by further research. Such research might include (a) split dose research on living animals, e.g drosophila, zebra fish, (b) comparison of sequential decay effects from indentical elements with different decay sequences e.g. Sr-90/Y-90 vs. Sr-89.

\begin{tabular}{lll}
\hline \multicolumn{1}{c}{ External dose comparison } & $\begin{array}{c}\mathbf{2}^{\text {nd }} \text { Event } \\
\text { enhancement probability [19] }\end{array}$ & $\begin{array}{c}\text { Cox and Edwards (2000)[59] } \\
\text { Cox Edwards and Simmonds (2004) } \\
\text { [6] }\end{array}$ \\
\hline $1 \mathrm{mGy}$ & 30 & 1.3 \\
\hline $0.1 \mathrm{mGy}$ & 200 & 8.6 \\
\hline $0.01 \mathrm{mGy}$ & 1900 & 82 \\
\hline $0.001 \mathrm{mGy}$ & 9400 & 407 \\
\hline 1 atom per g of tissue & $5 \times 10^{9}$ & \\
\hline
\end{tabular}

Table 5. Second Event Enhancements for Sr-90/Y-90 ( From Busby 1998 [19]) 


\subsection{Secondary photoelectron effects}

The quantity employed in radiation protection, absorbed dose, is defined as $\mathrm{D}=\Delta \mathrm{E} / \Delta \mathrm{M}$. Hitherto, the mass into which the energy has been diluted is that of living tissue; ICRU provide tables of absorption coefficients for different living tissue, adipose, bone, muscle etc. which can be employed for calculations involving doses, but generally all these denominator quantities have the absorption characteristics of water $\left(\mathrm{H}_{2} \mathrm{O}\right)$ (ICRU35 1984). The absorption of electromagnetic (photon) radiation is due to a number of processes, the main three being pair-production, Compton scattering and photoelectron production. For elements of atomic number greater than about 30, and for photon energies of less than about $500 \mathrm{keV}$, the photoelectric effect predominates. Even for the low atomic number elements that make up living systems, there is fairly quantitative conversion of incident photon radiation below 200 $\mathrm{keV}$ (and induced photon radiation from second order and third order processes) into photoelectrons. These are fast electrons which are indistinguishable from beta radiation and have the energy of the incident photon minus their binding energy (which is generally far less than the incident photon energy and can be ignored). The absorption of photon radiation by elements is proportional to the fourth or fifth power of the atomic number $Z$. Thus the predominant absorber in water is the Oxygen atom $Z=8$ and it is reasonable to give the effective atomic number of water as 7.5. Of course, there are elements in tissue with higher atomic numbers, but interestingly, apart from Iodine $(Z=53)$ few elements with $Z>26$ (Iron, $\mathrm{Fe}$ ).The incorporation of high $\mathrm{Z}$ elements into living systems would generally be harmful since it would increase the radiation dose, and therefore such developments have been lost though evolutionary selection. Iodine is an exception, but it should be noted that the main sites for radiation damage in terms of sensitivity are the main sites for Iodine concentration, the thyroid gland and the blood. It has been suggested that the metabolic and cell repair status controls exercised by the thyroid gland are the reason why Iodine has been incorporated into living systems and is employed as a kind of radiation-repair control mechanism [17].

A problem in radiation protection arises when high $\mathrm{Z}$ elements are incorporated into living tissue, since the enormously greater absorption of photon radiation by such material will result in enhanced doses to tissues adjacent to the high $\mathrm{Z}$ material. The problem was first addressed in 1947 in relation to X-rays of bone [64] and has been studied in the past in relation to prostheses. More recently, interest has shifted to the use of high $\mathrm{Z}$ material to enhance photon radiotherapies for tumour destruction where it has been shown to be effective. Gold nanoparticles have been successfully employed (and patented) for radiotherapy enhancement [65].

Despite this knowledge, the enhancement of photon radiation by high $\mathrm{Z}$ contaminants has not been addressed in radiation protection. The situation may have arisen out of the fact that prosthetic materials are not intrinsically radioactive and contamination from high $\mathrm{Z}$ elements like Lead $(Z=82)$ are considered under the heading of chemical toxicity. The issue was raised in $2005[66,67]$. It was pointed out that there are two circumstances where the Secondary Photoelectron Effect (SPE) would have significant radiological implications. These are (a) for high $\mathrm{Z}$ elements that bind to DNA and (b) for internal high Z particulates. In the latter case, the effect will increase as the particle size is reduced, since for massive high $Z$ con- 
tamination e.g. prostheses, most of the photoelectrons are wasted inside the bulk material. The emergence of the photoelectrons into tissue is a function of the mean electron path in the material, and the absorbed dose in local tissue is a function of the electron range and thus its energy.

The radiological implications of the idea emerged in considering the anomalous health effects of Depleted Uranium weapons and were presented to the CERRIE Committee in 2003 and the UK Ministry of Defence in 2004 although nothing was done. More recently there have been attempts to quantify the effects for particles through Monte Carlo modelling [68, 69], but these have not generally been very credible treatments or able to cope with the small volumes of complex media involved, and the results have been far removed from the few experimental data published $[70,65]$.

The particular concern is for the element Uranium, since this has been employed since 1991 as a weapon; the Depleted Uranium (DU) penetrators, used from the 1991 Persian Gulf War onward, produce a fallout comprising sub-micron Uranium Oxide particles which are environmentally mobile and respirable. Uranium has another quality which makes it of interest in SPE; as the uranyl ion $\mathrm{UO}_{2}{ }^{++}$it has a very high affinity for DNA phosphate: some $10^{10} \mathrm{M}^{-1}$ [30]. This affinity has been known since the 1960s when it was first employed as an electron microscope stain for imaging chromosomes [31].

The SPE is therefore likely here to cause enhanced photoelectron ionization at the DNA due to enhanced absorption of natural background radiation (or medical X-rays). A similar process occurs with the Platinum chemotherapeutic agent cisplatin which binds to the DNA and acts as an antenna for background radiation and radiotherapy beams.

For SPE phantom radioactivity in other elements of high atomic number, the tissue doses are enhancements of the incident photon dose at the point of the atom or particle being considered. Due to the complex interactions these local doses must be determined by experiment. However, these experiments are straightforward and involve X-irradiation of high $\mathrm{Z}$ element contaminated tissue at different doses. In principle, this development suggests that the internalization of any high $\mathrm{Z}$ particle which is biologically long-lived will cause continuous irradiation of local tissue cell populations, which would represent a carcinogenic hazard. This has implications for those employing prosthetic materials and also for the dispersion of high Z particles (Tungsten, Platinum, Bismuth, Lead) in the environment. It also suggests that it may be of interest to examine tumours for the presence of high $\mathrm{Z}$ particles at their centre. Table 6 lists a number of potentially hazardous SPE elements.

Finally it should be pointed out that physical modelling through Monte Carlo codes is unlikely to establish useful data and certainly should not be employed as an attempt to dismiss the importance of the proposed mechanism.

Nevertheless, a FLUKA Monte Carlo model of the absorption by nanoparticles of Gold and Uranium carried out by [71] Elsaesser et al 2007 graphically confirmed the effect. The results for photoelectron track production following absorption of $100 \mathrm{keV}$ photons is shown in Fig 6 below. Enhancement factor in this calculation for the 10nm Uranium particle relative to water was approximately 8000 . 

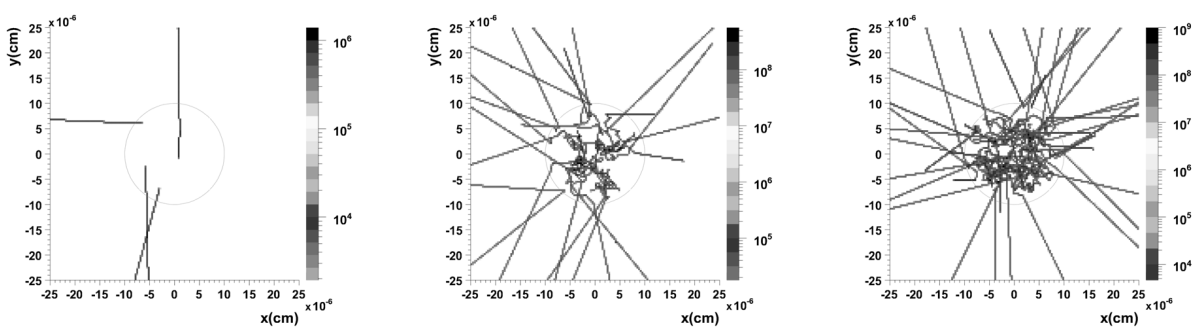

Figure 6. Photoelectron tracks emerging from (left to right) $10 \mathrm{~nm}$ particles of water ( $\mathrm{Z}=7.5$ ), Gold (Au; $\mathrm{Z}=79)$ and Uranium ( $(Z ;=92)$ after irradiation with $100 \mathrm{keV}$ photons. Monte Carlo (FLUKA code) analysis. Track numbers are in proportion to the $4^{\text {th }}$ power $\mathrm{Z}$ law (tracks are shown as projections on a flat plane). Note that the model uses 1000 incident photons for Au and $\mathrm{U}$ but 10,000 for water [71]

\begin{tabular}{|c|c|c|c|c|}
\hline Material & $\mathbf{Z}$ & $\mathrm{Z}^{4} /$ tissue & Source & Note \\
\hline$U$ & 92 & 22642 & $\begin{array}{l}\text { Weapons particles, nuclear fuel } \\
\text { cycle, atomic and thermonuclear } \\
\text { bomb tests }\end{array}$ & $\begin{array}{l}\text { Binds to DNA; known to cause cancer } \\
\text { in animals and genomic damage at } \\
\text { very low concentrations }\end{array}$ \\
\hline Th & 90 & 20736 & $\begin{array}{l}\text { Incandescent mantles } \\
\text { Contrast media }\end{array}$ & Highly insoluble \\
\hline $\mathrm{Bi}$ & 83 & 14999 & General contaminant & Insoluble \\
\hline $\mathrm{Pb}$ & 82 & 14289 & General contaminant & Toxic; SH binding \\
\hline $\mathrm{Hg}$ & 80 & 12945 & General contaminant & Toxic; enzyme binding \\
\hline $\mathrm{Au}$ & 79 & 12310 & $\begin{array}{l}\text { Prostheses; colloid used for } \\
\text { rheumatism }\end{array}$ & $\begin{array}{l}\text { Friction particles may travel in body; } \\
\text { inert and insoluble }\end{array}$ \\
\hline Pt & 78 & 11698 & $\begin{array}{l}\text { Vehicle catalysers, general } \\
\text { contaminant }\end{array}$ & Inert and insoluble \\
\hline W & 74 & 9477 & $\begin{array}{l}\text { Weapons; general particle } \\
\text { contaminant }\end{array}$ & $\begin{array}{l}\text { Associated with child leukemia cluster } \\
\text { Fallon Nevada; known to cause } \\
\text { genomic damage and cancer in } \\
\text { animals. }\end{array}$ \\
\hline Ta & 73 & 8975 & Capacitors & \\
\hline I & 53 & 2493 & Thyroid, blood plasma & Radiation sensitivity \\
\hline
\end{tabular}

Table 6. Biologically significant environmental contaminants and materials exhibiting phantom radioactivity through the Secondary Photoelectron Enhancement (SPE) of natural background and medical X-rays

\subsection{Fat soluble radioactive noble gases}

The nuclide Krypton-85 has been released to the biosphere continuously since 1945 and increasingly from nuclear energy processes. With a half-life of $10.7 \mathrm{y}$ and a $\beta$ decay of $672 \mathrm{keV}$ 
the concentration in the atmosphere has been building up to the extent that liquid air is now significantly radioactive. The assessment of harm from $\mathrm{Kr}-85$ has generally been associated with skin doses from $\beta$ decays in air. However Krypton (and Radon) are far more soluble in fats than in water and this water/oil partition driven equilibrium might cause build up of these nuclides in lymphatic tissue as a result of equilibria in the lung.

\section{Conclusions and recommendations.}

\subsection{Epidemiology: Uranium effects}

The current radiation risk position, that of the ICRP and its associated organisations, has been adequately reviewed by Harrison and Day [72]. With regard to the questions raised in the present overview, the only useful discussion in this paper, as in the CERRIE majority report [6], is the belief that the application of external risk models to internal exposures is supported by epidemiological studies of Thorotrast and Radium. It is therefore worth briefly looking more closely at these.

\subsection{Radium and thorotrast studies: Re-examining the data}

The increasing pressure brought to bear on the ICRP risk model focuses intensely on the arguments about internal and external radiation exposure rehearsed in the previous section. The ICRP and the radiation protection agencies have to concede much of the science, but fall back on the epidemiology. The problem is, very little human epidemiologic research has been done on internal radionuclide exposures. There are, however, two sets of studies which are said to broadly support the arguments that the current risk model is correct. These are the studies of individuals medically treated with Radium and Thorotrast. The studies originally were carried out because of doubt over the use of the external based risk model to deal with internal radionuclide exposures at a time when internal exposures from alpha emitters like plutonium were increasing in proportion to the development of the A-Bombs and $\mathrm{H}$ Bombs. All of these studies were of roughly the same type. A group of individuals was formalised and then records were traced, or the individuals themselves were traced to see what the number of cancers were. The end point was always cancer, since the project was to see if the ICRP cancer risk model was accurate for these internal exposures. The medical and other (e.g. laboratory) exposures to Radium had been largely before 1960; e.g radium clock dial painters, and there were many of these who had survived from the period when they were employed. In addition there were individuals who had been exposed to Ra-224 as a treatment for various illnesses. There had been a fashion to treat syphilis, hypertension, gout, infectious polyarthritis, "muscular rheumatism", anaemia, epilepsy and multiple sclerosis [29] with radium. Then there were many individuals who had been injected with the substance Thorotrast, an X-ray contrast medium based on the nuclide Th-232, the daughter of which is Ra-228. So these are all internal radium exposures. What was reported in studies was that the cancer yields, mainly of liver cancer, bone cancer, and leukaemia could be roughly related to the exposures and that the yield was not too far away from the yield predicted by the 
ICRP external type of risk model, i.e. the A-Bomb survivors. These studies are the last remaining defence that the current risk agencies can mobilise. There are a number of fatal problems with all the radium studies:

- The study groups were assembled long after the exposures and so not all those who had been exposed were in the study group: only the survivors. Many were dead. This biased the samples.

- A number of published studies give sufficient data to show that there was a high rate of death in the early period before the groups were assembled.

- The doses were not isotropic; for Thorotrast, the material was stored in depots in parts of the body where cells were quite resistant to radiation.

In addition, the doses were very large, so these studies were not of low dose chronic exposure but were in fact high dose internal chronic exposure.

Some of these problems were raised in 1970 in relation to the pioneering work by Robley Evans. Evans was a physicist and was concerned with the question of physical dosimetry of small quantities of internal emitters. Writing in the British Journal of Cancer in 1970, JF Loutit [29] took issue with the methodology of the Radium studies and pointed out that the massive bone marrow damage resulting from Radium exposure (which had been reported by many authors before Evans) would result in a very large excess death rate from a range of diseases. Loutit wrote that the limiting hazard from internally retained radium acquired occupationally being bone cancer needed to be reconsidered. He pointed out that evidence already existed in the 1930s from the work of Martland that those with substantial body burdens of radium had considerable life shortening and that the associated pathology had not been clarified. Loutit re-examined the radium dial case reports and found that internal radium had a profound effect on the bone marrow, best described as leukopenic anemia. This identifies one source of increased risk from non cancer illness and death which would have removed individuals from Radium and Thorotrast study groups. Indeed, the problem with all these studies is that they exclude about half of the exposed population who may have been lost to the researchers but are very likely to have died of cancer or a range of non cancer illnesses. In the better reported studies, where more data is made available, it is possible to see that this is indeed the case. An example is Wick et al. (1983) who examined cancer in Ra-224 patients. I have reduced the data from a diagram in this paper to produce the graph in Fig 7 which shows the percentage dead in the age group at exposure by the period between exposure and death. It is clear from the trend that for all the groups, the most deaths will have occurred in the first five years in individuals that were not in the study group.

This Ra-224 study by Wick et al. [73] is of the exposure group of German patients who were treated between 1948 and 1975 with Ra-224 for ankylosing spondylitis. There were 1501 total patients, among them 69 were missing and 433 were dead. What did they die of? We don't hear. But 3 of them developed bone cancer, 5 developed leukemia, and 6 bone marrow failure (cf Loutit above). This tiny cancer yield may approximate to the range predicted by the ICRP model (assuming that the dose could be accurately descri- 
bed) but what about the missing people? What about the 433 who died? If they died of conditions caused by the stress on their immune system (bone marrow failures and silent bone marrow problems) then the cancer yield is not a proper representation of the effects of the radium exposures on this group. And the cancer yield to produce an approximation to the ICRP risk predictions for leukemia is lower than in the control group. Addition of a handful of cases from the missing individuals or a handful of pre-leukemic immune-compromised individuals from the 633 dead would have a profound effect on the outcome of the study.

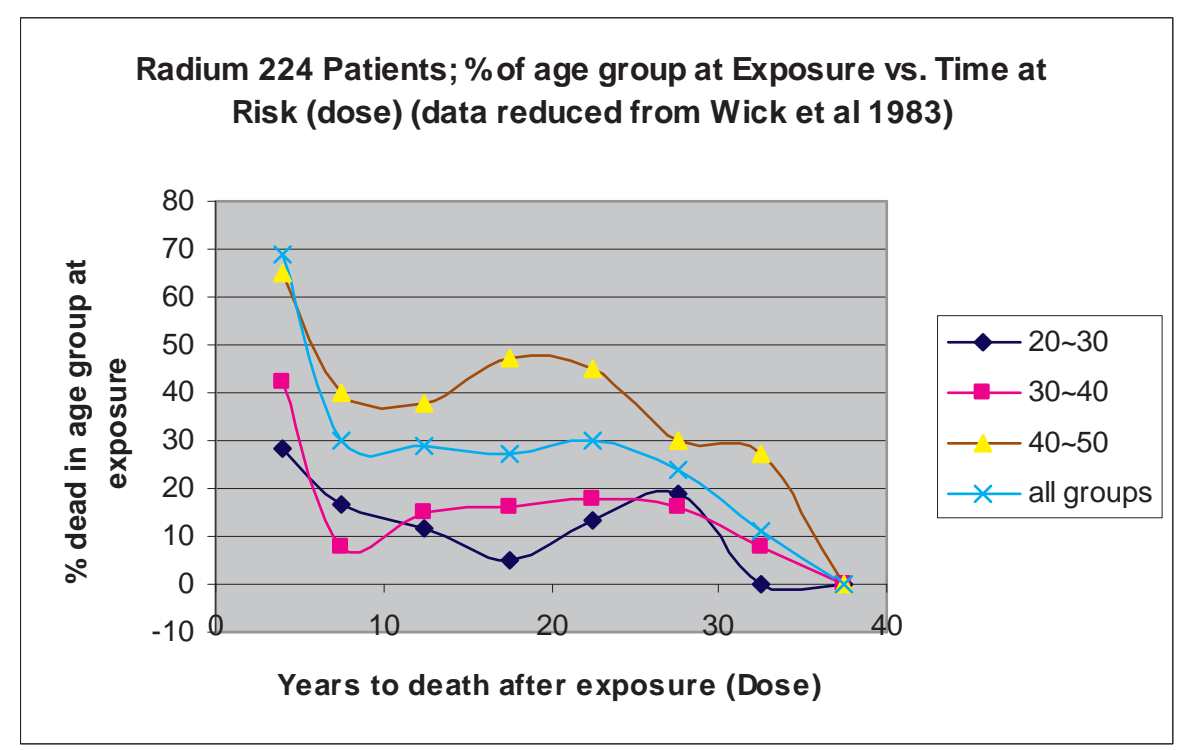

Figure 7. Percentage of each age group at exposure plotted against years to death from exposures in the Ra-224 study of Wick et al 1983. [73]

A similar picture is found in the thorotrast studies, where it is possible to see enough data. For example, in the paper by Mori et al 1983, 282 Japanese war wounded ex-servicemen thorotrast cases are followed up [74]. There were deaths from liver cancer, cirrhosis of the liver and also blood diseases. But in 170 deaths in the group, $42 \%$ were from cancer and $37 \%$ from other causes. There was no dose response for the cancers and the cancer yield was about 20-times greater than expected from ICRP. But the most interesting aspect is that from analysis of this group, the death rate was very high and the age at death very low compared with all Japanese populations. This is missed in the report since the method employed was to choose sick pathology controls from a hospital pathology records sample. I have compared their age specific death rates with all-Japan. Plots of the survival curves in the females in this group show that $100 \%$ were dead by age 75 compared with $65 \%$ for the equivalent all-Japan population. Results are given in Fig 8. 
Of course, about $40 \%$ of these study group women died of cancer: the effects of the thorotrast. But note that the others died from something else; they didn't live to a ripe old age nor did they live as long as the all Japan population. This is clear from the survival curves in Figure 8 which show almost a 20 years age effect in the women. For men, the shift was about 9 years (my unpublished results, not shown).

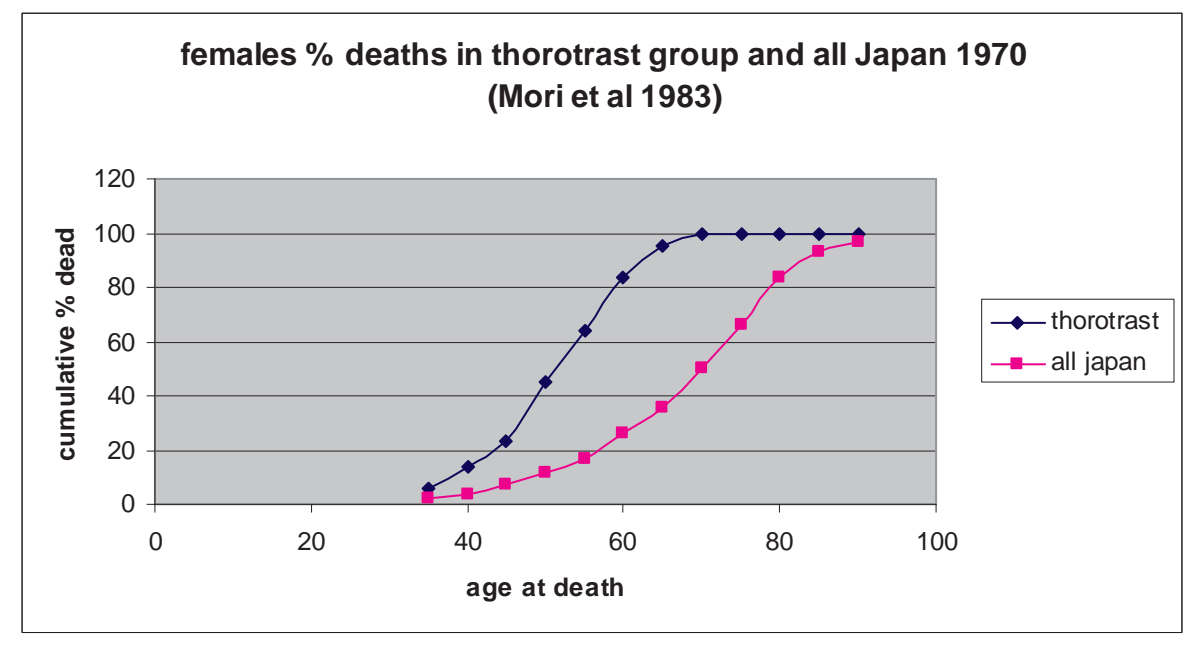

Figure 8. Survival curves for female thorotrast patients studied by Mori et al 1983 compared with all Japan. Data reduced from tables in Mori et al 1983 [74] and Japanese government publications.

The conclusions of this brief account of the re-examinations of the radium and thorotrast studies show that they cannot be used as indicators for low dose chronic risk to internal radionuclides. Apart from the fact that the doses were (like the A-Bomb doses) very large, the main fatal flaw was and is that confounding causes of death make the cancer yield conclusions unsafe. Loutit 1970 makes the point that the damage to the bone marrow would be likely to occur in the case of the weapons-fallout component Strotium-90, and he urged the research community to concentrate on examining risk from that nuclide, an exhortation which the research community entirely failed to take notice of. Loutit was a Medical Research Council MRC (Harwell) director.

\subsection{Uranium}

The anomalous health effects of exposure to Uranium, especially in the form of particulates, have been increasingly clear in the last 10 years. The radiobiological evidence is reviewed in ECRR2009 [75] and there is insufficient space here to do more than note that the current risk external radiation based model cannot begin to explain or predict what is found empirically. Despite the massive evidence including studies by nuclear industry and military scientists, the agencies ICRP, UNSCEAR, BEIR et al persist in their assertions that the observed effects 
cannot be due to Uranium. Most recently there have been studies of French Uranium workers showing leukemia and lymphoma excess, lung cancer excess and heart disease at doses which are too low by some 2000-times to explain them on the basis of current risk models $[76,77,78]$. There is an urgent need to carry out research into this issue. The effects of photoelectron amplification can easily be examined by studies involving varying external X-ray doses at different concentrations of Uranium particulates and molecular Uranyl ion in cell culture and animal studies. There is no routine measurement of Uranium in the vicinity of nuclear sites. This should also be remedied.

\section{4. other epidemiological evidence}

\subsubsection{Childhood cancer near nuclear installations}

There have been reports in peer reviewed journals of increased risk of childhood leukemia and non Hodgkin lymphoma near many nuclear sites in Europe. A list and discussion may be found in ECRR2010. Child leukemia excesses are found near nearly all the sites that have been examined [5]. e.g the reprocessing sites at Sellafield [37] Dounreay UK [79] and La Hague (France) [80] near the Atomic Weapons Establishment Aldermaston (UK) [81], the Atomic Energy Research Establishment Harwell (UK) [82], near Hinkley Point nuclear power station (UK) [83] and recently near all the combined nuclear sites in Germany (KiKK study) [84] and near all the combined nuclear sites in France [85], GB, and Switzerland.

The radiation risk community [86, 87] basing calculations on the ICRP risk model have worked out the dose ranges and say they cannot be more than a few microSieverts, well below Natural Background. The ICRP risk model predicts an excess risk of 0.05 cancers per Sievert. 100 microSieverts is 1/10,000 th ( $10^{-4}$ of a Sievert). An Excess Absolute Risk of 0.05/Sv is Excess Relative Risk (ERR) of $5 \mathrm{E}-8$ per $\mu$ Sv. This, divided by the spontaneous risk of $3 \mathrm{E}-4$ for $0-4$ y old children, is $1 \mathrm{E}-3$ per 6 microSv. But there are twice as many child leukemias as are expected: a doubling of risk: the ERR observed in the KiKK study was $\sim E R R=1$. So ICRP predicts a 1000-fold lower risk than found in the KiKK study.)

The ICRP does not give a risk factor for childhood leukaemia but to define a difference between external and internal exposure we can employ the Excess Relative Risk based on the obstetric X-ray studies analysed by Wakeford and Little [88]. This gives an Excess Relative Risk of 50/Sv and based on the 40/Sv Obstetric X-rays results of Alice Stewart.

Stewart found a $40 \%$ excess risk after an X-ray dose of $10 \mathrm{mSv}$ [88]. That would suggest a $4 \%$ increase after $1 \mathrm{mSv}, 0.4 \%$ after $100 \mu \mathrm{Sv}$. But we are seeing a $100 \%$ increase at this level. The error is now $100 / 0.4=250$-fold.

\subsubsection{Infant leukemia after Chernobyl}

Five different groups [89-93] reported a statistically significant increase in infant leukemia in 5 different countries of Europe in those children who were in the womb at the time of the Chernobyl Caesium-137 fallout as measured by whole body monitoring. The effect was also reported from the USA [94]. Thus the Chernobyl exposure is the only explanation for the in- 
crease. This occurred and was reported from Greece, Germany, Scotland, Wales, Belarus, USA and the error this shows in the ICRP model was the subject of two peer reviewed papers in 2000 [92] and 2009 [25]. Using the Alice Stewart relation between dose and leukemia above, the error is about 400-fold (depending on the country) [25]. Using the ICRP model it is upwards of 1000-fold. This analysis is most relevant since it unequivocally supports the causal relation revealed by the nuclear site child leukemias yet in this case fission product internal radiation can be the only cause.

\subsubsection{Cancer following Chernobyl in Northern Sweden}

The study by Martin Tondel found a 11\% increase in cancer for every $100 \mathrm{kBq} / \mathrm{sq}$ metre of Cs-137 from Chernobyl [95]. It is possible to calculate that $100 \mathrm{kBq} / \mathrm{m}^{2}$ Cs-137 including a further $100 \mathrm{kBq}^{\prime} \mathrm{m}^{2}$ of Cs-134 if reduced exponentially due to rain washout to rivers and lakes with half life of 6 months would give a committed effective dose of about $1 \mathrm{mSv}$. The ICRP model [96] predicts an Excess Relative Risk of 0.45 per Sv, so the ICRP expected excess relative risk, including a Dose Rate Reduction Factor of 2 (as used by ICRP) is $0.0225 \%$. The error in ICRP model defined by Tondel's result is thus 490 -fold.

\subsubsection{Human sex ratio at birth perturbed by low doses of internal fission-product ionising radiation}

Studies by Hagen Scherb and Kristina Voigt [97] show clear and highly statistically significant alterations in the human sex ratio at birth (the number of boys born to girls) after (a) atmospheric bomb testing, (b) Chernobyl and (c) near nuclear facilities. Effects are shown to be local, European (several countries were studied) and global, supporting earlier evidence of increases in infant mortality during the period of atmospheric weapons testing [98, 99]. Sex ratio has been accepted as a measure of genetic damage with the preferential killing of one or other sex depending on the type of exposure (mothers or fathers). According to Scherb and Voigt, millions of babies were killed in utero by these effects [100]. A recent reanalysis of the sex ratio effect in Hiroshima reveals the effect in those populations also [101], evidence which was overlooked by the USA researchers through poor epidemiology and questionable decisions. This evidence objectively confirms the serious genotoxic effect of internal ionising radiation on germ cells and the exquisite sensitivity of humans and other living creatures to releases from Uranium fission. The ICRP does not consider such effects nor are they included in any assessment of harm.

\subsubsection{Cancer and genotoxic effects in Iraq following DU exposure}

A series of studies of the population of Fallujah Iraq shown [102- 104] to have been exposed to Uranium following the 2003-2004 battles have revealed extremely high rates of congenital malformations at birth and cancer and leukemia/lymphoma in adults. The studies also draw attention to significant sex ratio effects at birth beginning after 2004. These results, and the increases in genotoxic effects in the offspring of Gulf veterans support and are supported by the other sets of observations reviewed above which show that inhaled Uranium nanoparticles represent a very serious hazard which is entirely overlooked by ICRP. 


\subsubsection{Chernobyl effects as reported in the Russian peer-reviewed literature}

The effects of the Chernobyl accident exposures have been reported in the Russian language peer review literature since 1996. These results have been reviewed by Busby and Yablokov 2006 [105] Yablokov et al 2010 [106] and Busby et al 2011 [107] but have been largely ignored by ICRP. They constitute a very large body of peer reviewed work which show that the effects of the Chernobyl accident exposures are massive and extremely serious [108]. They range from cancer and leukemia to heart disease especially in children together with a range of illnesses which can be best described by the term premature ageing [108]. They include congenital transgenerational diseases and are reported in animals and plants which cannot be affected by the kind of psychological processes (radiophobia) which have been employed by the radiation risk establishment to account for the early reports coming out of the affected territories. In addition, there are objective measurements of serious biological harm to humans and other living creatures affected by the exposures. The germline mutations found by minisatellite tests [109] in humans were also associated with real morphological effects and fitness loss in birds [110] and were shown to have caused significant sex ratio changes in the birds and also population loss [111] which is in agreement with the findings of Scherb and Voigt and the infant mortality findings [98, 99]. The implications for the understanding of the historic effects of the nuclear project on human health are alarming.

\subsection{Summary and conclusions}

The current radiation risk model is insecure for internal radionuclide effects. Massive evidence exists from epidemiology and also published studies of the effects of internal radionuclide exposures that the effects of location, chemical binding or affinity, temporal decay patterns and transmutation of internal radionuclides can have much greater genetic or lethal effects on cells than are predicted by the absorbed dose model. These data have been published since the 1950s but ignored for the purpose of radioprotection. Many critical research issues should have been pursued but have not been. It is recommended that those issues and research studies highlighted in this contribution are seen as a priority.

\section{Appendix}

\section{Calculating the probability of a track interception with DNA as a function of distance of the point source}

The model is given in Fig 9 and Fig 10. It locates the source at the centre of a sphere $S$ radius $r$ distance $d$ from the DNA which is modelled as a cylinder of length $2 \mathrm{R}$. We put $\mathrm{r}<\mathrm{D}$. Any decay which intercepts an infinitesimal strip of area A on the DNA cross section can be mapped onto a small area B on the surface of the sphere S. The required probability assumes that the decay can be in any direction. It is thus equal to the area B / total area of the sphere. 


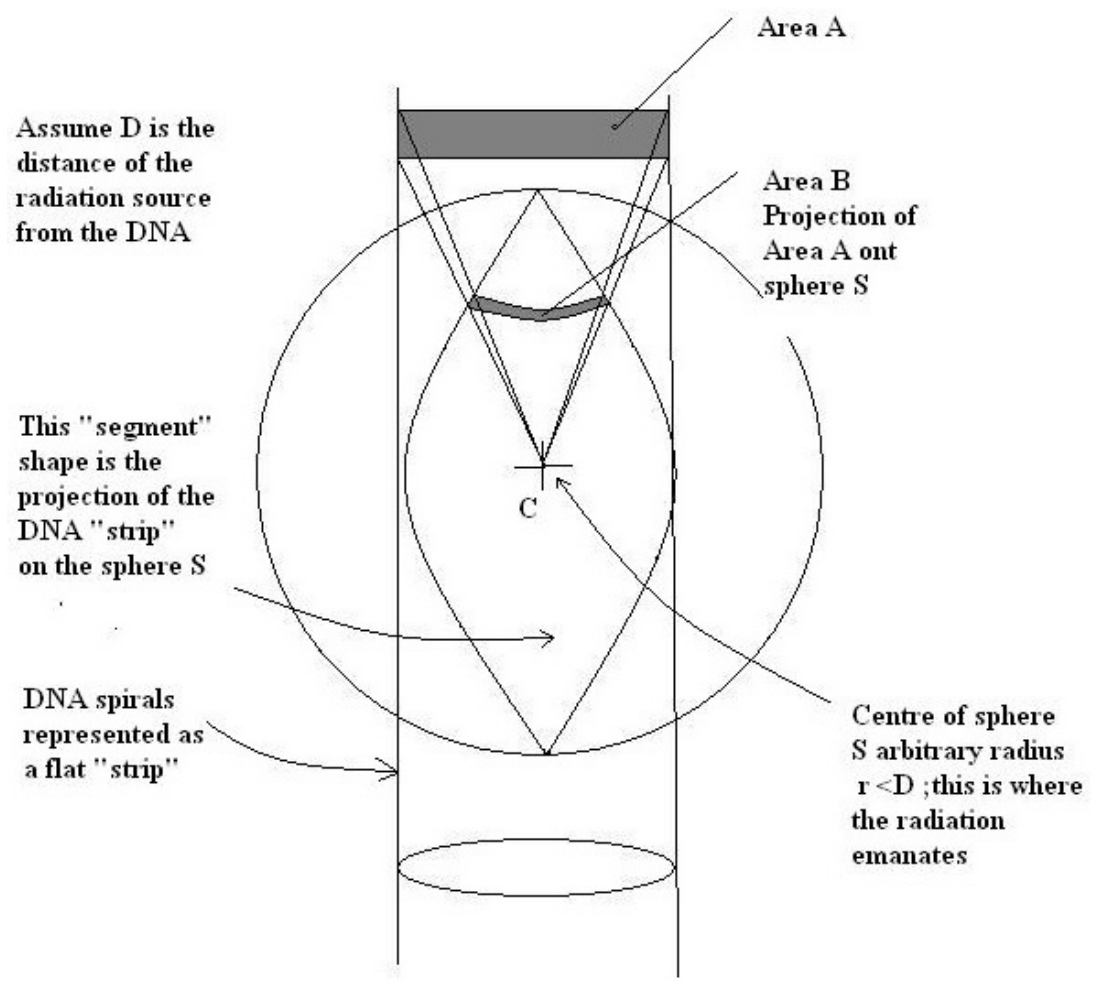

Figure 9. Model

From Fig 2, $\tan \theta=\mathrm{R} / \mathrm{d} ; \theta=\arctan (\mathrm{R} / \mathrm{d})$

Length of $\operatorname{arc} A=2 r \theta=2 \arctan (R / d)$

$\mathrm{d}^{\prime}=\mathrm{d} / \cos \theta ; \theta=\arctan \left(\mathrm{R} / \mathrm{d}^{\prime}\right)=\arctan ((\operatorname{Rcos} \alpha) / \mathrm{d})$

Area B (Fig 1) $=2 \mathrm{r} \theta \cdot \operatorname{rd} \alpha=2 \mathrm{r}^{2} \arctan ((\operatorname{Rcos} \alpha) / \mathrm{d})$ 

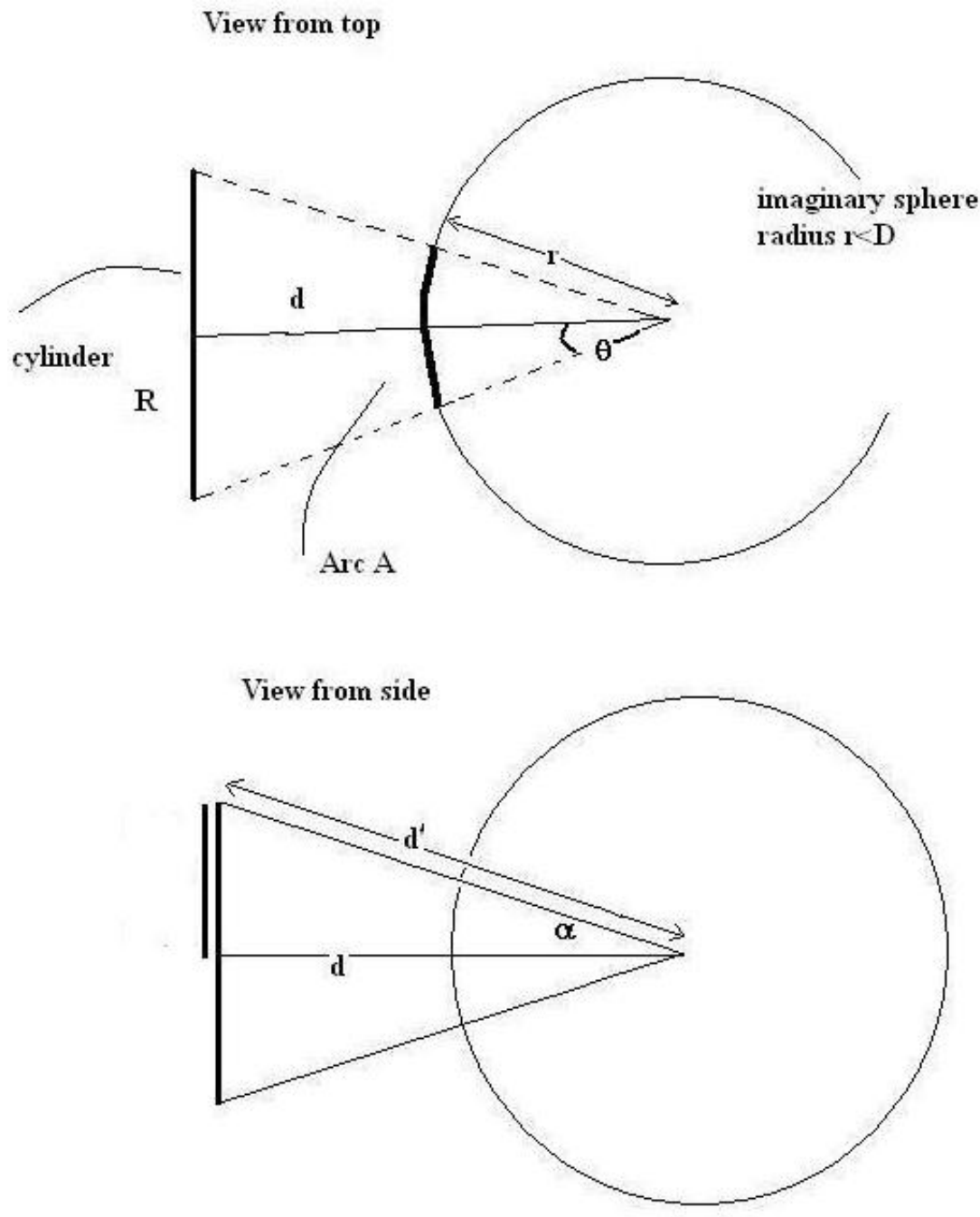

Figure 10. Model from top and side

Area B (Fig 1) $=2 \mathrm{r} \theta \cdot \mathrm{rd} \alpha=2 \mathrm{r}^{2} \arctan ((\operatorname{Rcos} \alpha) \mathrm{d})$

Whole area of segment $=$ $4 r^{2} \int_{0}^{\pi / 2} \arctan ((R \cos \alpha) / d) d \alpha$

And the required probability is this divided by the surface area of the sphere $4 \pi r^{2}$ $\mathrm{P}(\mathrm{DNA})=\frac{1}{\pi} \int_{0}^{\pi / 2} \arctan ((R \cos \alpha) / d) d \alpha$ 


\section{Author details}

Christopher Busby

Jacobs University, Bremen, Germany

\section{References}

[1] Caufield, K. (1989), Multiple Exposure: Chronicles of the Radiation Age (London: Secker and Warburg).

[2] Gracheva LM and Korolev VG (1980) Genetic effects of the decay of radionuclides in cells. Edited by I.A.Zacharov. Calcutta: Oxonian Press PVT

[3] ICRP Publication 72 (1996) Age-dependent Doses to the Members of the Public from Intake of Radionuclides Part 5, Compilation of Ingestion and Inhalation Coefficients. Amsterdam: Elsevier

[4] ECRR2003 (2003) 2003 recommendations of the European Committee on Radiation RiskThe health effects of ionizing radiation at low dose--Regulator's edition. Busby C.C editor with Bertell R, Yablokov A, Schmitz Feuerhake I and Scott Cato M (Brussels: ECRR-2003) Translations of the above into French Japanese Russian and Spanish (see www.euradcom.org for details)

[5] ECRR2010 (2010) The 2010 Recommendations of the European Committee on Radiation Risk. The Health Effects of Ionizing Radiation at Low Doses and Low Dose Rates. Eds. Busby C, Yablolov AV, Schmitz Feuerhake I, Bertell R and Scott Cato M Brussels: ECRR; Aberystwyth Green Audit

[6] CERRIE (2004) Report of the Committee Examining Radiation Risk from Internal Emitters (CERRIE) Chilton, UK: National Radiological Protection Board

[7] Busby CC, Bramhall R and Dorfman P (2004) CERRIE Minority Report 2004: Minority Report of the UK Department of Health/ Department of Environment (DEFRA) Committee Examining Radiation Risk from Internal Emitters (CERRIE) Aberystwyth: Sosiumi Press

[8] IRSN (2005) Les consequences sanitaire des contaminations internes chroniques par les radionucleides. Ed:-F.Paquet Rapport DRPH/2005-20 Fontenay aux Roses: Institut de Radioprotection et de Surete Nucliare

[9] UNSCEAR, (1977) Sources and Effects of Ionising Radiation, Report to the General Assembly, with annexes, (New York, United Nations).

[10] Busby, C. (1994), Increase in Cancer in Wales Unexplained, BMJ, 308: 268.

[11] Busby C.C (2002). 'High Risks at low doses.' Proceedings of 4th International Conference on the Health Effects of Low-level Radiation: Keble College Oxford, Sept 24 2002. (London: British Nuclear Energy Society). 
[12] BEIR V (1990) BEIR (Committee on Biological Effects of Ionising Radiation), (1990) The Health Effects of Exposure to Low Levels of Ionising Radiation, BEIR V, (Washington: National Academy Press).

[13] Mothershill C and Seymour C (2012) Human and environmental health effects of low doses of radiation. In Fukushima-What to expect. Proceedings of the $3^{\text {rd }}$ International Conference of the European Committee on Radiation Risk, Lesvos, Greece May 5/6 2009 Eds Busby C, Busby J, Rietuma D and de Messieres M. Brussels, Belgium: ECRR

[14] Baverstock, K.F. \& Charlton, D.E. 1988. DNA Damage by Auger Emitters. Taylor and Francis, London

[15] Hofer KG (1998) Biophysical aspects of Auger Processes- a review. Acta Oncol.35 798-96

[16] Ward, J.F., Limoli, P., Calabro-Jones, P. \& Evans, W.F. 1988. Radiation vs.chemical damage to DNA. In: Nygard, O.F., Simic, M. \& Cerutti, P. (eds.), Anticarcinogenesis and Radiation Protection. Plenum, New York.

[17] Busby Chris and Schnug Ewald (2008) Advanced biochemical and biophysical aspects of uranium contamination. In: (Eds) De Kok, L.J. and Schnug, E. Loads and Fate of Fertilizer Derived Uranium. Backhuys Publishers, Leiden, The Netherlands, ISBN/EAN 978-90-5782-193-6.

[18] Busby, C.C. (1995), Wings of Death: Nuclear Pollution and Human Health (Aberystwyth: Green Audit)

[19] Busby, C.C.(1998), 'Enhanced mutagenicity from internal sequentially decaying beta emitters from second event effects.' In 'Die Wirkung niedriger Strahlendosen- im kindes-und Jugendalter, in der Medizin, Umwelt ind technik, am Arbeitsplatz'. Proceedings of International Congress of the German Society for Radiation Protection. Eds: Koehnlein W and Nussbaum R. Muenster, 28 March 1998 (Bremen: Gesellschaft fur Strahlenschutz)

[20] Goodhead DT (1991) Biophysical features of radiation at low dose and low dose rate. In CB Seymour and C Mothershill (Eds) New Developments in fundamental and applied radiobiology London: Taylor and Francis.

[21] Apelgot S and DBuguesne M (1963) Energie dissipee par le Tritium dans les microorganisms. Int.J.Radiation Biol. 7 (1) 65-74

[22] Robertson JS and Hughes WL (1959) Intranuclear irradiation with Tritium labeled thymidine. In: Proc $1^{\text {st }}$ National Biophysical Conference Columbus Ohio 278-283

[23] ICRU 35 (1984) Radiation Dosimetry: Electron Beams with energies between 1 and 50MEv. Bethesda MD USA: ICRU

[24] Burlakova E B; Goloshchapov A N, Zhizhina G P, Konradov A A, (2000) New aspects of regularities in the action of low doses of low level irradiation. In Low Doses of Ra- 
diation-Are They Dangerous? Burlakova E B, Ed.; Nova Science Publishers: New York, NY, USA,

[25] Busby C.C. (2009) Very Low Dose Fetal Exposure to Chernobyl Contamination Resulted in Increases in Infant Leukemia in Europe and Raises Questions about Current Radiation Risk Models. International Journal of Environmental Research and Public Health.; 6(12):3105-3114. http://www.mdpi.com/1660-4601/6/12/3105

[26] Luning, K. G., Frolen, H., Nelson, A., and Ronnbaeck, C. (1963), 'Genetic Effects of Strontium-90 Injected into Male Mice', Nature, No 4864 197: 304-5.

[27] Smirnova, E. I. and Lyaginska, A. M. (1969), 'Heart Development of Sr-90 Injured Rats', in Y. I. Moskalev and Y. I. Izd (eds.), Radioaktiv Izotopy Organizs (Moscow: Medizina), 348

[28] Stokke, T., Oftedal, P. and Pappas, A. (1968), 'Effects of Small Doses of Radioactive Strontium on the Rate Bone Marrow', Acta Radiologica, 7: 321-9.

[29] Loutit J F (1970), Malignancy from Radium. Brit.J.Cancer 24(2) 17-207

[30] Nielsen, P.E, Hiort, C., Soennischsen, S.O., Buchardt, O., Dahl, O. \& Norden, B. 1992. DNA binding and photocleavage by Uranyl VI salts. J. Am. Chem. Soc. 114: 4967-4975.

[31] Huxley, H.E. \& Zubay, G. 1961. Preferential staining of nucleic acid containing structures for electron microscopy. Biophys. Biochem. Cytol. 11: 273.

[32] Petkau A (1980) Radiation carcinogenesis from a membrane perspective Acta Physiologica Scandinavica suppl. 492. 81-90

[33] Tamplin AR and Cochran TB (1974) Radiation standards for hot particles. A report on the inadequacy of existing radiation standards related to exposures of man to insoluble particles of plutonium and other alpha emitting hot particles. Washington, USA: Natural Resources Defence Council

[34] Charles MW, Mill AJ and Darley P (2003) Carcinogenic risk from hot particles. J.Radiol.Prot. 23 5-28

[35] Popplewell, DS, Ham GJ, Dodd NJ, Shuttler SD (1988) ‘Plutonium and Cs-137 in autopsy tissues in Great Britain' Sci. Tot. Environment 70 321-34

[36] Priest, N. D., O’Donnell, R.G., Mitchell, P. I., Strange, L., Fox, A., Henshaw, D. L., and Long, S. C. (1997), 'Variations in the concentration of plutonium, strontium-90 and total alpha emitters in human teeth collected within the British Isles', Science of the Total Environment, 201, 235-243.

[37] Beral V E. Roman, and M. Bobrow (eds.) (1993), Childhood Cancer and Nuclear Installations (London: British Medical Journal).

[38] Independent Advisory Group (1984), Investigation of the Possible Increased Incidence of Cancer in West Cumbria, The Black Report, (London: HMSO). 
[39] Royal Society (2001) The Health Effect of Depleted Uranium Weapons Vol 1 London: Royal Society

[40] COMARE, (1996) The Incidence of Cancer and Leukaemia in Young People in the Vicinity of the Sellafield Site in West Cumbria: Further Studies and Update since the Report of the Black Advisory Group in 1984, COMARE 4th Report (Wetherby: Department of Health).

[41] Hohenemser C, Deicher M, Hofsass H, Lindner G, Recknagel E and Budnick J (1986) Agricultural impact of Chernobyl: a warning. Nature 321817

[42] Apelgot S (1968) Effect letal de la disintegration des atomes radioactifs (3H, 14C, 32P) incorpres dans bacteria. In: Biological Effects of Transmutation and decay of incorporated Radioisotopes. Vienna: IAEA 147-163

[43] Apelgot S and Latarjet R (1962) Marquage d'un acide deoxyribonucleique bacterien par le radiophosphore, le radiocarbone at le tritium: comparison des effets letaux. Biochim et Biophys Acta 55(1) 40-55

[44] Andersen FA and Person S (1971) Incorporation of 14C labeled precursors into e.coli The lethal and mutagenic effects. Radiation Res. Abstr. 47 (1) p261

[45] Andersen FA and Person S (1973) Incorporation of 14C labeled precursors into e.coli The lethal and mutagenic effects. Radiation Res. Abstr. 21 (1) p4

[46] Pluchnnik G (1965) Mutagenyii protsess u khorelly pri assimilatsii radioaktivnoi uglekiskoty (mutagenic process in Chlorella during assimilation of radioactive carbon dioxide) Genetika 1(5) 19-25)

[47] Pluchennik G (1966) Comparative study of mutagenic effects of incorporated isotopes of the most important organogenic elements. Report 1. Mutagenic effects of incorporated $14 \mathrm{C}$ from the example of reversion to autotrophy of diploid yeasts that are homozygous in relation to mutations for adenine requirement. (Russian) Genetika 2(5) $117-124$

[48] Totter IR, Zerle MR and Hollister H (1958) Hazards to man of Carbon-14. Science 128 1490-1495

[49] Pauling L (1958)Genetic and somatic effects of Carbon-14 Science 128 1183-1186

[50] Beal JM (1950) Chromosome aberrations in onion roots from plants grown in an atmosphere containing 14- $\mathrm{CO}_{2}$. Amer.J.Botany 37 660-661

[51] Beal M and Scully NJ (1950) Chromosome aberrations in onion roots from plants grown in an atmosphere containing 14- $\mathrm{CO}_{2}$. Botan.Gas112 232-235

[52] McQuade HA, Friedkin M and Atchison AA (1956) Radiation effects of thymidine $2-{ }^{14} \mathrm{C}$. 1 . Uptake of thymidine $2-{ }^{14} \mathrm{C}$ and thymine $2-{ }^{14} \mathrm{C}$ in the onion root tip. 2 . Chromosomal aberrations caused by thymidine $2-{ }^{14} \mathrm{C}$. and thymine $2-{ }^{14} \mathrm{C}$ in the onion root tip. Expt.Cell.Res. 11 (2) 249-264 
[53] McQuade HA and Friedkin M (1960) Radiation effects of thymidine ${ }^{3} \mathrm{H}$ and thymidine ${ }^{14}$ C. Expt.Cell.Res. 21(1) 118-125

[54] Kuzin AM (1962) Biological effects of increased concentrations of ${ }^{14} \mathrm{C}$ in the atmosphere (Russian) in Radiation Genetics Izd-vo AN SSSR Moscow 274-278

[55] Kuzin AM (1962) Effectiveness of biological action of ${ }^{14} \mathrm{C}$ when incorporated in live cells. In Radionatsionnaya Genetika Izd-vo AN SSSR Moscow 267-273

[56] Purdom CE (1965) Genetic effect of incorporated ${ }^{14} \mathrm{C}$ in D.MelanogasterMutation Res. 2(2) 156-167

[57] Kuzin AM, Glembotskii Ya M, Lapkin Yu A (1964) Mutagenic efficiency of incorporated Carbon 14. (Russian) Radiobiologiya 4(6) 804-809

[58] Jha AM, Dogra Y, Turner A and Millward GE (2005) Impact of low doses of tritium on the marine mussel myrtilis edulis. Genotoxic effects and tissue specific bioconcentrations. Mutat.Res 56(1) 47-57

[59] Cox R and Edwards A (2000) Commentary on the Second Event Theory of Busby Int.J.Radiat.Biol 76(1) 119-125

[60] Busby C.,(2000), 'Response to Commentary on the Second Event Theory by Busby' International Journal of Radiation Biology 76 (1) 123-125

[61] Gracheva LM and Shanshiashvili TA (1983) Genetic effects of decay of radionuclide products of fission of nuclear fuel II.Lethal and mutagenic effects on the mutation of cells of the yeast saccharomyces cerevisiae induced by Sr-90 and Sr-89. Genetika (Moscow) $9 / 4532-5$

[62] Miller RC and Hall EJ (1978) X-ray dose fractionation and oncogenic transformations in culture mouse embryo cells. Nature 272 58-60

[63] Borek C and Hall EJ (1974Rffects of split doses of X-rays on Neoplastic transformation of single cells Nature 252 499-501

[64] Speirs, F.W. 1949. The influence of energy absorption and electron range on dosage in irradiated bone. Brit. J. Radiol. 22: 521-533.

[65] Hainfeld, J.F., Slatkin, D.N. \& Smilowitz, H.M. 2004. The use of gold nanoparticles to enhance radiotherapy in mice. Phys. Med. Biol. 49: N309-N315.

[66] Busby CC (2005) Does uranium contamination amplify natural background radiation dose to the DNA? European J. Biology and Bioelectromagnetics. 1 (2) 120-131

[67] Busby CC (2005) Depleted Uranium Weapons, metal particles and radiation dose. European J. Biology and Bioelectromagnetics. 1(1) 82-93

[68] Pattison J E, Hugtenburg R P, Green S, (2009) Enhancement of natural background gamma-radiation dose around uranium micro-particles in the human body. J.Royal http://rsif.royalsocietypublishing.org/content/early/2009/09/23/rsif.2009.0300.abstract 
[69] Eakins, JS, Jansen J. Th. M. and Tanner R. J. (2011) A Monte Carlo analysis of possible cell dose enhancements effects by Uranium microparticles in photon fields Radiation Protection Dosimetry (2011), Vol. 143, No. 2-4, pp. 177-180 doi:10.1093/rpd/ncq398

[70] Regulla, D.F., Hieber, L.B. \& Seidenbusch, M. 1998. Physical and biological interface dose effects in tissue due to X-ray induced release of secondary radiation from metallic gold surfaces. Radiat. Res. 150: 92-100

[71] Elsaesser A, Busby C, McKerr G and Howard CV (2007) Nanoparticles and radiation. EMBO Conference: Nanoparticles. October 2007 Madrid

[72] Harrison J and Day P (2008) Radiation doses and risks from internal emitters. J Radiol.Prot. 28 137-159

[73] Wick RR, Chmelevsky,D and Goessner W (1984) Risk to bone and haematopoetic tissue in ankylosing spondilitis patients. In W.Goessner, GB Gerber, U Hagen and A Luz. Eds The radiobiology of radium and thorotrast. Munich Germany: Urban and Schwartzenberg

[74] Mori T, Kumatori T, Kato Y, Hatakeyama S, Kamiyama R, Mori W, Irie H, Maruyama T and Iwata S (1983) Present status of medical study of thorotrast patients in Japan. Pp123-135 . In W.Goessner, GB Gerber, U Hagen and A Luz. Eds The radiobiology of radium and thorotrast. Munich Germany: Urban and Schwartzenberg

[75] ECRR2009 (2009) The health effects of exposure to Uranium. Brussels: ECRR (www.euradcom.org)

[76] Guseva Canu I, Laurier D, Caër-Lorho S, Samson E, Timarche M, Auriol B, Bérard P, Collomb P, Quesned B, Blanchardone E (2010) Characterisation of protracted lowlevel exposure to uranium in the workplace: A comparison of two approaches. International Journal of Hygiene and Environmental Health 213 (2010) 270-277

[77] Guseva Canu, Irina, Garsi, Jerome-Philippe, Cae ${ }^{\circ}$-Lorho Sylvaine, Jacob SophieCollomb, Philippe, Acker Alain, Laurier Dominique (2012) Does uranium induce circulatory ? First results from a French cohort of uranium workers Occup. Envir. Med. OEM Online First, published on March 3, 2012 as 10.1136/oemed-2011-100495

[78] Guseva Canu I, Jacob S Cardis E, Wild P Cae ${ }^{\circ} \mathrm{r}$-Lorho S, Auriol B, Garsi JP, Tirmarche M, Laurier D (2010) Uranium carcinogenicity in humans might depend on the physical and chemical nature of uranium and its isotopic composition: results from pilot epidemiological study of French nuclear workers. Cancer Causes Control DOI 10.1007/s10552-011-9833-5

[79] Urquhart T D, Black R T, Muirhead M T, et al., (1991) Case-control study of leukaemia and non-Hodgkins lymphoma in children in Caithness near the Dounreay nuclear installation. British Medical Journal; 302:687-692.

[80] Viel J-F, Poubel D, Carre A, (1995) Incidence of leukaemia in young people and the La Hague nuclear waste reprocessing plant: a sensitivity analysis. Statistics in Medicine, 14, 2459-2472. 
[81] Busby C, and M. Scott Cato, (1997)'Death Rates from Leukemia are Higher than Expected in Areas around Nuclear Sites in Berkshire and Oxfordshire', British Medical Journal, 315 (1997): 309

[82] Busby C, and M. Scott Cato, (1997)'Death Rates from Leukemia are Higher than Expected in Areas around Nuclear Sites in Berkshire and Oxfordshire', British Medical Journal, 315 (1997): 309

[83] Bowie C, Ewings P D, (1988) Leukaemia incidence in Somerset with particular reference to Hinkley Point, Taunton: Somerset Health Authority.

[84] Kaatsch P, Spix C, Schulze-Rath R, Schmiedel S, Blettner M, (2008) Leukaemias in young children living in the vicinity of German nuclear power plants. Int J Cancer 122 , pp. 721-726.

[85] Sermage-Faure Claire, Laurier Dominique, Goujon-Bellec Stéphanie, Chartier Michel, Guyot-Goubin, Aurélie, Rudant Jérémie, Hémon Denis, Clavel Jacqueline (2012) Childhood leukemia around French nuclear power plants - The geocap study, 20022007 International Journal of Cancer Volume 131 (5) E769-E780 DOI: 10.1002/ijc. 27425

[86] COMARE (Committee on Medical Aspects of Radiation in the Environment), (1986) The Implications of the New Data on the Releases from Sellafield in the 1950s for the Conclusions of the Report on the Investigation of a Possible Increased Incidence of Cancer in West Cumbria, COMARE 1st Report (London: HMSO).

[87] NRPB, (1995) Risks of leukaemia and other cancers in Seascale from all sources of ionising radiation NRPB R-276 (Chilton: NRPB).

[88] Wakeford R and Little MP (20030) Risk coefficients for childhood cancer after intrauterine irradiation. A review. Int.J.Rad.Biol. 79 293-309

[89] Michaelis J, Kaletsch U, Burkart W and Grosche B, (1997) Infant leukaemia after the Chernobyl Accident Nature 387, 246.

[90] Petridou E, Trichopoulos D, Dessypris N, Flytzani V, Haidas S, Kalmanti M, Koliouskas D, Kosmidis H, Piperolou F, Tzortzatou F, (1996) Infant Leukaemia after in utero exposure to radiation from Chernobyl, Nature, 382:25, 352.

[91] Gibson B E S, Eden O B, Barrett A, et al., (1988) Leukaemia in young children in Scotland, The Lancet, 630

[92] Busby, C. C. and Cato, M. S. (2000), 'Increases in leukemia in infants in Wales and Scotland following Chernobyl: evidence for errors in risk estimates' Energy and Environment 11(2) 127-139 92 Busby C.C. and Cato M.S. (2001) 'Increases in leukemia in infants in Wales and Scotland following Chernobyl: Evidence for errors in statutory risk estimates and dose response assumptions'. International Journal of Radiation Medicine 3 (1) 23

[93] Busby C.C. (2009) Very Low Dose Fetal Exposure to Chernobyl Contamination Resulted in Increases in Infant Leukemia in Europe and Raises Questions about Current 
Radiation Risk Models. International Journal of Environmental Research and Public Health.; 6(12):3105-3114. http://www.mdpi.com/1660-4601/6/12/3105

[94] Mangano J, (1997) Childhood leukaemia in the US may have risen due to fallout from Chernobyl, British Medical Journal, 314: 1200.

[95] Tondel M, Hjalmarsson P, Hardell L, Carisson G, Axelson A, (2004) Increase in regional total cancer incidence in Northern Sweden. J Epidem. Community Health. 58 1011-1016.

[96] ICRP, (2007) The 2007 recommendations of the International Commission on Radiological Protection. ICRP 103 Orlando USA: Elsevier

[97] Scherb H and Voigt K (2010) The human sex odds ratio at birth after the atmospheric bomb tests, Chernobyl, and in the vicinity of nuclear facilities. Env.Sci.Pollut.Res. Int 18 (5) 697-707

[98] Sternglass E J, (1971) Environmental Radiation and Human Health, in Proceedings of the Sixth Berkeley Symposium on Mathematical Statistics and Probability, ed. J. Neyman (Berkeley, Calif.: University of California Press).

[99] Whyte R K, (1992) First Day Neonatal Mortality since 1935: A Re-examination of the Cross Hypothesis, British Medical Journal, 304: 343-6.

[100] Scherb H and Voigt K (2011) in Busby C, Busby J, Rietuma D and de Messieres M Eds. (2011) Fukushima: What to Expect. Proceedings of the $3^{\text {rd }}$ International Conference of the European Committee on Radiation Risk May 5/6 ${ }^{\text {th }}$ Lesvos Greece. Brussels: ECRR; Aberystywth UK: GreenAudit

[101] Padmanabhan VT (2011) in Busby C, Busby J, Rietuma D and de Messieres M Eds. (2011) Fukushima: What to Expect. Proceedings of the $3^{\text {rd }}$ International Conference of the European Committee on Radiation Risk May 5/6 $6^{\text {th }}$ Lesvos Greece. Brussels: ECRR; Aberystywth UK: GreenAudit

[102] Alaani Samira, Tafash Muhammed, Busby Christopher, Hamdan Malak and Blaurock-Busch Eleonore (2011) Uranium and other contaminants in hair from the parents of children with congenital anomalies in Fallujah, Iraq Conflict and Health 2011, 5:15 doi:10.1186/1752-1505-5-15

[103] Busby, Chris; Hamdan, Malak; Ariabi, Entesar. (2010) Cancer, Infant Mortality and Birth Sex-Ratio in Fallujah, Iraq 2005-2009. Int. J. Environ. Res. Public Health 7, no. 7: 2828-2837. doi:10.3390/ijerph7072828

[104] Alaani S, Al Fallouji M, Busby C and Hamdan M (2012) Pilot study of congenital rates at birth in Fallujah, Iraq, 2010 J. Islam. Med. Assoc. N. Amer. Sept $1^{\text {st }} 2012$

[105] Busby C, Yablokov A V $(2006,2009)$ ECRR 2006. Chernobyl 20 years On. The health Effects of the Chernoby lAccident Aberystwyth: Green Audit 
[106] Yablokov A V, Nesterenko V B, Nesterenko A V, (2009) Chernobyl: Consequences of the Catastrophe for people and the environment. Annals of the New York Academy of Sciences. Vol 1181 Massachusetts USA: Blackwell

[107] Busby C, Busby J, Rietuma D and de Messieres M Eds. (2011) Fukushima: What to Expect. Proceedings of the $3^{\text {rd }}$ International Conference of the European Committee on Radiation Risk May 5/6 $6^{\text {th }}$ Lesvos Greece. Brussels: ECRR; Aberystwyth UK: GreenAudit

[108] Malko M V, (1998) Chernobyl accident: the crisis of the international radiation community in Imanaka T: Research activities about the radiological consequences of the Chernobyl NPS accident and social activities to assist the sufferers of the accident. (Kyoto University: Research Reactor Institute).

[109] Dubrova Y E, Nesterov V N, Jeffreys A J et al., (1997) Further evidence for elevated human minisatellite mutation rate in Belarus eight years after the Chernobyl accident. Mutation Research 381 267-278.

[110] Ellegren H, Lindgren G, Primmer C R, Moeller A P, (1997), Fitness loss and Germline mutations in Barn Swallows breeding in Chernobyl, Nature 389/9, 583-4.

[111] Møller AP, Bonisoli-Alquati A, Rudolfsen G, Mousseau TA (2012) Elevated Mortality among Birds in Chernobyl as Judged from Skewed Age and Sex Ratios. PLoS ONE 7(4): e35223. doi:10.1371/journal.pone.0035223 
